OPEN ACCESS

Edited by:

Rohan Mahendra Shah,

Swinburne University of

Technology, Australia

Reviewed by:

Vipin Kumar Singh,

Banaras Hindu University, India

M. Leonor Faleiro,

University of Algarve, Portugal

*Correspondence:

David Julian McClements

mcclemen@umass.edu

Arun K. Das

arun.das@icar.gov.in

Specialty section:

This article was submitted to

Agro-Food Safety,

a section of the journal

Frontiers in Sustainable Food Systems

Received: 17 December 2020

Accepted: 22 January 2021

Published: 18 February 2021

Citation: McClements DJ, Das AK, Dhar P, Nanda PK and Chatterjee N (2021) Nanoemulsion-Based Technologies for Delivering Natural Plant-Based Antimicrobials in Foods.

Front. Sustain. Food Syst. 5:643208.

doi: 10.3389/fsufs.2021.643208

\section{Nanoemulsion-Based Technologies for Delivering Natural Plant-Based Antimicrobials in Foods}

\author{
David Julian McClements ${ }^{1 *}$, Arun K. Das ${ }^{2 *}$, Pubali Dhar ${ }^{3,4}$, Pramod Kumar Nanda ${ }^{2}$ and \\ Niloy Chatterjee ${ }^{3,4}$ \\ ${ }^{1}$ Department of Food Science, University of Massachusetts, Amherst, MA, United States, ${ }^{2}$ Eastern Regional Station, \\ ICAR-Indian Veterinary Research Institute, Kolkata, India, ${ }^{3}$ Laboratory of Food Science and Technology, Food and Nutrition \\ Division, University of Calcutta, Kolkata, India, ${ }^{4}$ Center for Research in Nanoscience \& Nanotechnology, University of \\ Calcutta, Kolkata, India
}

There is increasing interest in the use of natural preservatives (rather than synthetic ones) for maintaining the quality and safety of foods due to their perceived environmental and health benefits. In particular, plant-based antimicrobials are being employed to protect against microbial spoilage, thereby improving food safety, quality, and shelf-life. However, many natural antimicrobials cannot be utilized in their free form due to their chemical instability, poor dispersibility in food matrices, or unacceptable flavor profiles. For these reasons, encapsulation technologies, such as nanoemulsions, are being developed to overcome these hurdles. Indeed, encapsulation of plant-based preservatives can improve their handling and ease of use, as well as enhance their potency. This review highlights the various kinds of plant-based preservatives that are available for use in food applications. It then describes the methods available for forming nanoemulsions and shows how they can be used to encapsulate and deliver plant-based preservatives. Finally, potential applications of nano-emulsified plant-based preservatives for improving food quality and safety are demonstrated in the meat, fish, dairy, and fresh produce areas.

Keywords: antimicrobials, antioxidants, plant-based, encapsulation, nanoemulsions, nanopesticides, food quality, food safety

\section{INTRODUCTION}

Food preservation technologies increase the safety, quality, and shelf-life of food products, thereby reducing food waste and enhancing the sustainability of the food supply (Pardo and Zufía, 2012). Researchers are therefore continually trying to optimize the efficacy of traditional preservation methods, as well as develop new ones (Bhadekar and Bhola, 2019). Some of the most common preservation approaches involve the thermal processing of foods. Typically, the foods are heated at temperatures ranging from 60 to $100^{\circ} \mathrm{C}$ for times ranging from a few seconds to a few minutes to inhibit spoilage and pathogenic microorganisms. However, these processes do have some limitations because they can cause undesirable changes in food quality, loss of vital nutrients, involve high energy costs, and utilize valuable resources (Teixeira, 2014). For these reasons, there is growing interest in developing non-thermal preservation methods to overcome these problems (Barba et al., 2018). In particular, there has been an interest in utilizing natural preservatives isolated from animal, plant, or microbial sources because of consumer demand for a more sustainable and healthy food supply (Sharif et al., 2017; Das et al., 2020b). Nevertheless, these ingredients 
must be developed taking into account economic factors, regulatory restrictions, toxicity problems, customer concerns, etc. (Davidson et al., 2014).

A wide variety of natural substances have been examined for their potential utilization as preservatives in foods, including phytochemicals derived from various botanical sources (Bouarab Chibane et al., 2019; Das et al., 2020b, 2021b), as well as essential oils, such as those isolated from clove (Syzygium aromaticum), eucalyptus (Eucalyptus globulus), basil (Ocimum basilicum), black pepper (Piper nigrum), cannabis (Cannabis sativa), citronella (Cymbopogon nardus), and rosemary (Salvia rosmarinus) plants (Chouhan et al., 2017; Falleh et al., 2020). In general, plants are a rich source of natural antimicrobial agents, and researchers are actively working to identify, characterize, and utilize them (Quinto et al., 2019; Rao et al., 2019; Srivastava et al., 2020). However, many plant-based antimicrobials cannot simply be utilized in their free form due to their chemical instability, poor dispersibility in food matrices, or unacceptable flavor profiles. As a result, encapsulation technologies, such as emulsion-based systems, are being developed and employed to overcome these problems. Emulsions are widely used for this purpose because they can simply and affordably be produced using food-grade ingredients and processing operations. A welldesigned delivery system can improve the handling, ease of use, stability, and potency of plant-based preservatives.

In this review, we focus on the utilization of oil-in-water nanoemulsions as delivery systems for natural antimicrobials. We begin by reviewing the properties of different kinds of natural preservatives. We then highlight the formulation, fabrication, and properties of nanoemulsion-based delivery systems. Finally, we provide specific examples of the application of antimicrobial nanoemulsions to foods.

\section{PLANT-BASED ANTIMICROBIALS}

A wide range of natural substances with antimicrobial activity have been identified in plant-based edible materials (Goel et al., 2020). Many plants produce secondary metabolites and other substances to protect themselves from invading pathogens, such as microorganisms (bacteria, fungi, and viruses), insects, and herbivores. These plant-derived compounds can be categorized into different groups depending on their botanical source, chemical structure, or mechanism of action. Plant extracts, such as herbs and spices, have already been used for centuries in foods for their antimicrobial activities, as well as for their flavors and fragrances (Fan et al., 2018). Herbs and spices exhibit different antimicrobial activities against different foodborne microorganisms depending on their constituents (Tajkarimi et al., 2010; Savoia, 2012). Recently, there has been interest in isolating natural antimicrobials from waste materials recovered from the food and agricultural industries, such as fruit and vegetable waste products (Varzakas et al., 2016; Quinto et al., 2019). Detailed information about different classes of natural antimicrobials have been given elsewhere (Cowan, 1999; Savoia, 2012; Ud-Daula et al., 2016; Meneguetti et al., 2017; Quinto et al., 2019; Rao et al., 2019; Srivastava et al., 2020). The major groups of antimicrobial phytochemicals are summarized in Table 1. In this section, we highlight some of the most important plant-based substances with antimicrobial activity.

\section{Phenols and Polyphenols}

Phenols and polyphenols are secondary metabolites that are produced by many plants to defend themselves from microbes, insects, and herbivores. Many phenolics are potent antioxidants that can inhibit oxidative changes (such as lipid, phospholipid, or protein oxidation) due to their metal chelating and free radical scavenging properties (Dai and Mumper, 2010; Das et al., 2021b). The major group of phenols and polyphenols include simple phenols, simple phenolic acids, flavonoids, quinines, tannins, and coumarins (Figure 1).

\section{Simple Phenols and Phenolic Acids}

Simple phenols and phenolic acids consist of a single substituted phenolic ring, which may have one or more hydroxyl groups attached, such as cinnamic and caffeic acids (Cowan, 1999; Othman et al., 2019). The toxicity of these molecules to microorganisms is related to the site(s) and degree of hydroxylation, with higher inhibitory activity linked to a more oxidized structure (Cowan, 1999). The mode of action of these phenolics has been attributed to inhibition of critical microbial enzymes, possibly due to their reaction with sulfhydryl or other functional groups on the enzyme surfaces (Cowan, 1999; Savoia, 2012; Coppo and Marchese, 2014). Other researchers have suggested that the antibacterial activity of phenolic acids is due to disruption of membrane integrity, which results in leakage of essential intracellular components (Borges et al., 2013), direct alteration of microbial metabolism, and inactivation of essential substrates required for microbial growth (Dietrich and Pour Nikfardjam, 2017). The ability of phenolics to inhibit bacteria by altering their surface properties is shown schematically in Figure 2. For example, ferulic acid has been found to decrease the hydrophobicity of Pseudomonas aeruginosa and alter bacterial polarity by interfering with surface electron acceptors on both Gram-positive and Gram-negative strains (Borges et al., 2013). Recently, Liu J. et al. (2020) provided a detailed account of the antibacterial effect of various phenolic acids against both food-borne pathogens and human pathogenic strains.

\section{Flavonoids}

Flavonoids are a class of natural molecules typically isolated from flowers and fruits, which are reported to exhibit potent antimicrobial and antioxidative activities (Górniak et al., 2019). Flavonoids have a 2-phenyl-benzo- $\gamma$-pyrane core comprising of two benzene rings (Rings A and B) linked through a heterocyclic pyran or pyrone (Ring C). Flavonoids can be classified into various groups based on their level of oxidation and unsaturation, such as flavones, isoflavones, flavan-3-ols (catechins), flavanones, and anthocyanidins (Cowan, 1999; Falcone Ferreyra et al., 2012). These secondary plant metabolites are synthesized in response to microbial infection and are reported to have strong antimicrobial action against a wide range of pathogenic microorganisms (Othman et al., 2019). For this reason, they are increasingly being explored for use in the pharmaceutical and healthcare 
TABLE 1 | Major classes of antimicrobial compounds, proposed mechanisms of action, and antimicrobial spectrum of plants and plant extracts.

\begin{tabular}{|c|c|c|c|c|}
\hline Class & Subclass & Example & Mechanism & Selected antimicrobial spectrum \\
\hline \multirow[t]{6}{*}{ Phenolics } & Simple phenols & Catechol, epicatechin, eugenol & $\begin{array}{l}\text { Substrate deprivation, } \\
\text { membrane disruption }\end{array}$ & $\begin{array}{l}\text { Listeria monocytogenes } \\
\text { Staphylococcus aureus } \\
\text { Escherichia coli O157:H7 } \\
\text { Salmonella enterica } \\
\text { Vibrio cholerae } \\
\text { Pseudomonas aeruginosa } \\
\text { Acinetobacter baumannii } \\
\text { Klebsiella pneumoniae } \\
\text { Aspergillus flavus } \\
\text { Penicillium sp. } \\
\text { Cladosporium sp. }\end{array}$ \\
\hline & Phenolic acids & $\begin{array}{l}\text { Cinnamic acid, P-coumaric acid, } \\
\text { ferulic acid, caffeic acid, vanillic } \\
\text { acid }\end{array}$ & $\begin{array}{l}\text { Enzyme inhibition, membrane } \\
\text { disruption, bind to cell wall } \\
\text { proteins }\end{array}$ & \\
\hline & Anthocyanins & Cyanidin, petunidin & - & \\
\hline & $\begin{array}{l}\text { Flavones } \\
\text { Flavonoids }\end{array}$ & $\begin{array}{l}\text { Apigenin, chrysin, rutin, catechin, } \\
\text { epicatechin }\end{array}$ & $\begin{array}{l}\text { Complex with cell wall, bind to } \\
\text { adhesins }\end{array}$ & \\
\hline & Flavanones & Abyssinone, naringenin, fisetin & $\begin{array}{l}\text { Inactivate enzymes, inhibit HIV } \\
\text { reverse transcriptase }\end{array}$ & \\
\hline & Quinones & $\begin{array}{l}\text { Anthraquinone, benzoquinone, } \\
\text { hypericin, naphthoquinone, } \\
\text { plastoquinone, pyrroloquinoline } \\
\text { quinone }\end{array}$ & $\begin{array}{l}\text { Bind to adhesins, inactivate } \\
\text { enzymes }\end{array}$ & $\begin{array}{l}\text { S. aureus, } P \text {. aeruginosa } \\
\text { Bacillus subtilis, } \\
\text { Cryptococcus neoformans }\end{array}$ \\
\hline \multirow[t]{2}{*}{ Tannins } & $\begin{array}{l}\text { Ellagitannin } \\
\text { Condensed tannins }\end{array}$ & $\begin{array}{l}\text { Tannic acid, gallic acid, } \\
\text { proanthocyanidins }\end{array}$ & $\begin{array}{l}\text { Bind to cell wall of bacteria and } \\
\text { inhibit their growth, bind to } \\
\text { proteins, bind to adhesins, inhibit } \\
\text { enzyme etc. }\end{array}$ & $\begin{array}{l}\text { Bacillus cereus, S. aureus, } \\
\text { L. monocytogenes, S. enterica, } \\
\text { Campylobacter jejuni }\end{array}$ \\
\hline & Coumarins & $\begin{array}{l}\text { Ammoresinol, warfarin, ostruthin, } \\
\text { anthogenol, agasyllin }\end{array}$ & Membrane disruption & $\begin{array}{l}\text { Salmonella Typhimurium, Salmonella } \\
\text { Enteritidis, Vibrio parahaemolyticus, } \\
\text { S. aureus, L. monocytogenes, E. coli } \\
\text { O157:H7 }\end{array}$ \\
\hline $\begin{array}{l}\text { Terpenoids, } \\
\text { essential } \\
\text { oils }\end{array}$ & Capsaicin & $\begin{array}{l}\text { Carotenoids, terpinene } \\
\text { Isopentenyl, pyrophosphate, } \\
\text { thymol, geraniol, linalool }\end{array}$ & $\begin{array}{l}\text { Destruct outer and inner } \\
\text { membrane, induce leakage, loss } \\
\text { of membrane integrity, changes } \\
\text { in cytoplasm }\end{array}$ & $\begin{array}{l}\text { Salmonella Typhi, S. aureus, } \\
\text { P. aeruginosa, V. cholerae }\end{array}$ \\
\hline Alkaloids & & Berberine, piperine & $\begin{array}{l}\text { Intercalate into cell wall and/or } \\
\text { DNA }\end{array}$ & $\begin{array}{l}\text { Proteus mirabilis, E. coli, } \\
\text { P. aeruginosa, S. aureus, } \\
\text { K. pneumoniae }\end{array}$ \\
\hline $\begin{array}{l}\text { Lectins } \\
\text { and } \\
\text { polypeptides }\end{array}$ & & $\begin{array}{l}\text { Mannose-specific agglutinin, } \\
\text { fabatin, concanavalin A, wheat } \\
\text { germ agglutinin, Aleuria aurantia } \\
\text { lectin }\end{array}$ & $\begin{array}{l}\text { Block viral fusion or adsorption } \\
\text { Form disulfide bridges }\end{array}$ & $\begin{array}{l}\text { Candida albicans, S. aureus, } \\
\text { B. subtilis, E. coli, P. aeruginosa }\end{array}$ \\
\hline
\end{tabular}

Adopted from Cowan (1999), Upadhyay et al. (2014), Zhang et al. (2016), Chouhan et al. (2017), Othman et al. (2019), Quinto et al. (2019), and Tanhaeian et al. (2020).

industries (Górniak et al., 2019). They are proposed to exert their antimicrobial activities by interacting with bacterial cell walls, thereby disrupting the cell membranes and interfering with critical biochemical pathways (Reygaert, 2014). The ability of many flavonoids to generate reactive oxygen species (ROS), such as epicatechin, epigallocatechin gallate, and quercetin, that can damage important cellular processes has also been proposed as a potential mechanism for their antioxidant activity (Fathima and Rao, 2016). Anthocyanins, which are another class of flavonoids, have also been reported to exhibit strong antibacterial activity against food-borne pathogens, such as Salmonella Enteritidis, Vibrio parahaemolyticus, Staphylococcus aureus, and Listeria monocytogenes. For instance, in a recent study, anthocyanins were shown to exert their antibacterial activities by damaging microbial cell membranes and interfering with critical biochemical pathways responsible for cell growth and reproduction (Sun et al., 2018). A comprehensive review of the antimicrobial activities of different flavonoids has been published recently (Górniak et al., 2019).

\section{Alkaloids}

Alkaloids are a structurally diverse group of secondary metabolites with broad antimicrobial activity that are distinguished by the fact they are heterocyclic nitrogenous compounds (Cushnie et al., 2014; Upadhyay et al., 2014). Based on the chemical structure, they can be divided into 


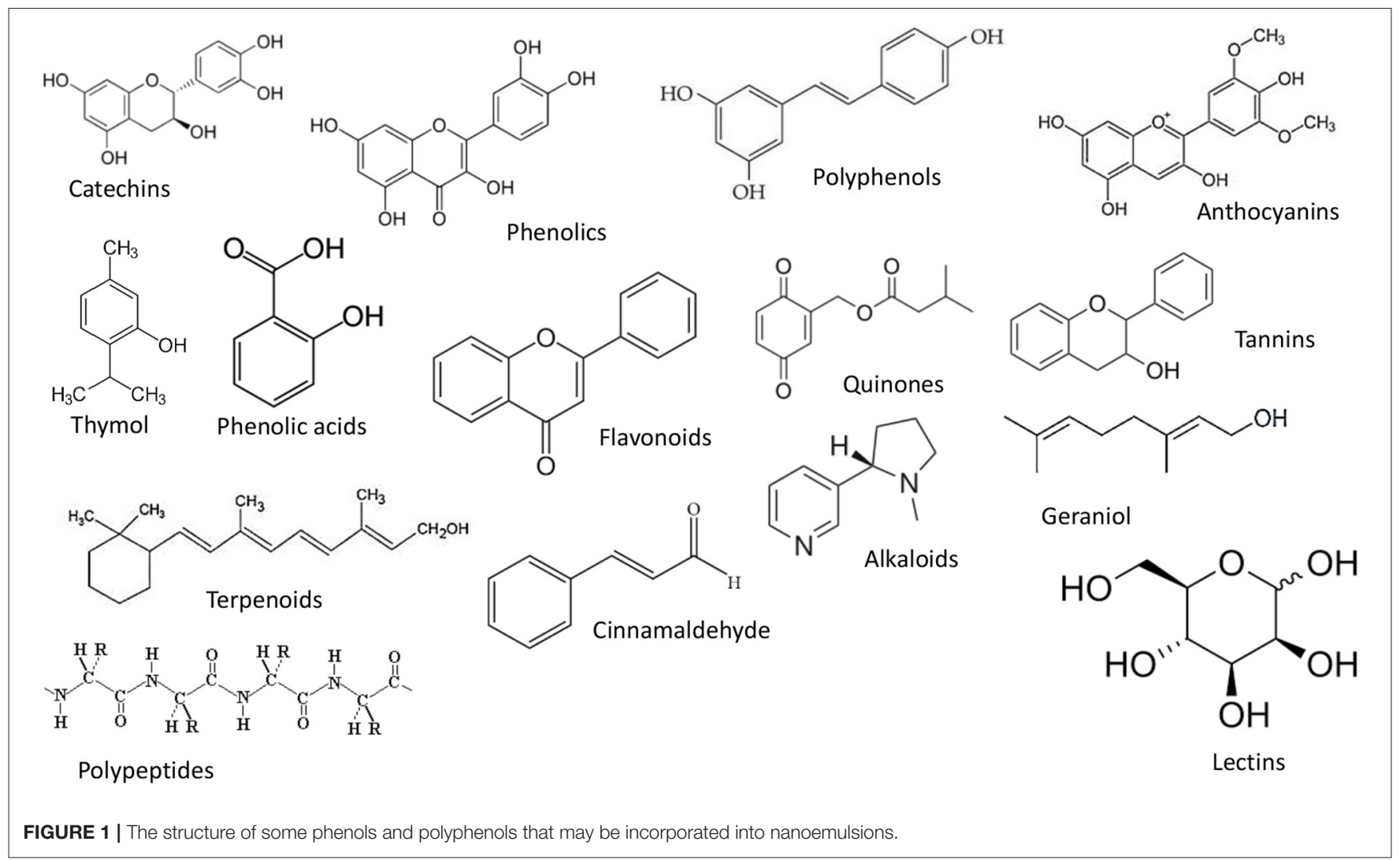

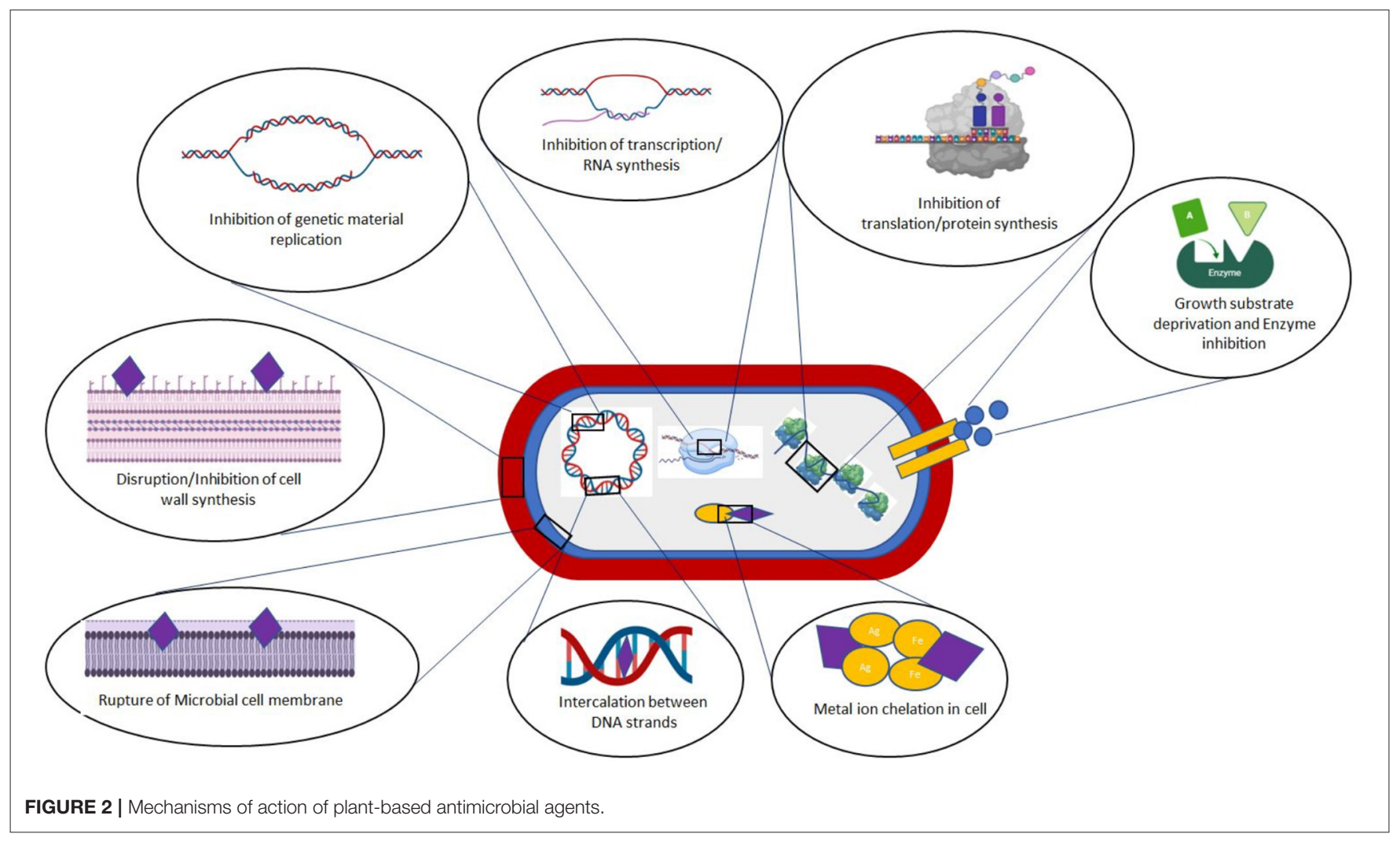


proto-alkaloids or atypical alkaloids (like hordenine or $\mathrm{N}$ methyltyramine, colchicine) having no heterocyclic compounds and typical alkaloids (such as hygrines belonging to the pyrrole and pyrrolidine group, and quinine belonging to the quinoline group) having heterocyclic compounds (Evans, 2009). Typical alkaloids are subdivided into different classes depending on the nature of the heterocyclic ring structure. The most common compounds in this group are codeine and morphine. Being secondary plant metabolites, alkaloids have been reported to have potent pharmacological activities including bacteriostatic, as well as bactericidal effects. As an example, plant alkaloids $(1.67 \mathrm{mg} / \mathrm{mL})$ isolated from Callistemon citrinus and Vernonia adoensis leaves prevented the growth of $S$. aureus and $P$. aeruginosa (Mabhiza et al., 2016). Indeed, these alkaloids have an efficacy comparable to that of ampicillin, a standard antibiotic. The alkaloids from C. citrinus also showed strong antimicrobial activity against $S$. aureus with a MIC of $0.0025 \mathrm{mg} / \mathrm{mL}$ and a minimum bactericidal concentration (MBC) of $0.835 \mathrm{mg} / \mathrm{mL}$ (Mabhiza et al., 2016). Diterpinoid alkaloids extracted from buttercups and the stem bark of Clausena anisata (Wild) were found to have good antibacterial properties (Upadhyay et al., 2014). Alkaloids from Achyranthes aspera (Amaranthaceae) plants were tested for their antibacterial activities against four species viz. Bacillus subtilis, Escherichia coli, P. aeruginosa, and S. aureus (Mishra, 2018). Alkaloids at a concentration of 40 $\mathrm{mg} / \mathrm{ml}$ showed the highest bacterial activity against $B$. subtilis. Sanguinarine, a benzophenanthridine alkaloid extracted from the root of Sanguinaria canadensis L., was found to possess inhibitory activity against methicillin-resistant $S$. aureus (MRSA) bacteria, which is an organism known for its resistance to almost all antibacterial agents (Obiang-Obounou et al., 2011). The antibacterial properties of plant alkaloids has been attributed to their ability to intercalate into cell wall or DNA within microbial cells (Savoia, 2012) and to inhibit the ATP-dependent transport of compounds across the cell membrane (Mabhiza et al., 2016), thereby leading to impaired cell division and cell death (Figure 2).

\section{Tannins}

Tannins are a class of water-soluble polyphenolic biomolecules mainly found in the major parts of higher plants, such as leaves, bark, fruits, and roots (herbaceous and woody plants) (Scalbert, 1991; Upadhyay et al., 2014). Traditionally, tannins have been used for tanning leather or precipitating gelatin from solution (Cowan, 1999). They are mainly categorized into two categories: hydrolyzable tannins (HTs) and condensed tannins (CTs). In the case of HTs like gallotannin, hydroxyl groups of a carbohydrate moiety are esterified with gallic acid or ellagic acid, whereas CTs, which are also commonly called proanthocyanidins (PAs) like catechin, are mainly composed of oligomers of the flavan-3-ols and other related flavanol residues mainly linked by carbon-carbon bonds and yield anthocyanidins on acid digestion (Akiyama et al., 2001). Catechins obtained from tea leaves are comprised mainly of epicatechin, epigallocatechin, epicatechin gallate, and epigallocatechin gallate (Scalbert, 1991; Hamilton-Miller, 1995). Tannins or tannin-rich plant extract have been reported to have high bacteriostatic or bactericidal effects against both Gram-positive and Gram-negative bacteria, such as S. aureus, P. aeruginosa, E. coli, Yersinia enterocolitica, Bacillus cereus, and Enterococcus faecalis (Pandey and Negi, 2018; Dabbaghi et al., 2019; Belhaoues et al., 2020). Major applications of tannins are in the leather, food, biomedical, and health care industries (Upadhyay et al., 2014; Kaczmarek, 2020). The antimicrobial activity of tannins is mainly due to inhibition of nutrient uptake by bacteria and interference with membrane transport proteins (Scalbert, 1991; Akiyama et al., 2001; Belhaoues et al., 2020). However, this activity depends on many factors, including the tannin concentration and type, microbial species, $\mathrm{pH}$, temperature, and food matrix effects (Kaczmarek, 2020).

\section{Coumarins}

Coumarins are a class of phenolic aromatic benzopyrones compounds that have fused benzene and alpha pyrone rings (Kennedy and Thornes, 1997). There are more than 1,300 coumarins identified and many of these exhibit antimicrobial activity (Upadhyay et al., 2014). Coumarins, such as aegelinol and agasyllin extracted from the roots of Ferulago campestris have been shown to exhibit strong antibacterial activity against S. aureus, Salmonella Typhi, Enterobacter cloacae, and Enterobacter aerogenes (Basile et al., 2009). The minimum inhibitory concentration MIC for aegelinol was $16 \mu \mathrm{g} / \mathrm{mL}$ whereas it was $32 \mu \mathrm{g} / \mathrm{mL}$ for agasyllin. Again, various pyrenylated coumarin compounds from dichloromethane extract of Prangos hulusii roots exhibited antimicrobial activity against B. subtilis and Klebsiella pneumoniae at a concentration between 5 and $125 \mu \mathrm{g} / \mathrm{mL}$ (Tan et al., 2017). In a recent study, coumarins, imperatorin, and chalepin (at a concentration of $20 \mu \mathrm{g} / \mathrm{mL}$ ) isolated from the root extract of plant $C$. anisata exhibited strong antibacterial activity against $S$. aureus and B. subtilis (Tamene and Endale, 2019).

\section{Terpenoids and Essential Oils}

Essential oils (EO) are an important source of plant-based preservatives that exhibit antimicrobial activity against various spoilage organisms and foodborne pathogens. EOs are extracted from various parts of plants, including leaves, flowers, seeds, barks, bulbs, buds, fruits, roots, and rhizomes (Chouhan et al., 2017). They often impart a characteristic aroma and taste to foods because of their unique composition. Commercially, steam distillation is the most frequently used method for the isolation of essential oils. Essential oils typically contain a complex mixture of numerous (20-80) volatile substances, including terpenes, terpenoids, phenols, and non-terpene compounds (Rao et al., 2019). Various factors impact the composition of essential oils, including geographical area, habitat, harvest time, storage conditions, and extraction methodology (UdDaula et al., 2016). For example, thyme oil extracted from Thymus vulgaris has six chemotypes based on the dominant component present, like thymol, carvacrol, linalool, geraniol, $\gamma$-terpineol, and complex trans-thujan-4-ol/terpinen-4-ol (Rao et al., 2019). 
The antibacterial activity of essential oils depends on their composition (Kordali et al., 2005; Hussain et al., 2008). For example, oregano oils exhibited greater antimicrobial activity against $L$. monocytogenes, $B$. cereus, $E$. coli, and P. aeruginosa when mixed with thyme oil than with pure oils (Gutierrez et al., 2008). Recently, in another study, the combination of clove (40\%), basil (20\%), and thyme (40\%) oil was reported to have a synergistic effect on the inhibition of yeasts and molds (Sharma et al., 2020). This synergistic effect not only improves their antimicrobial efficiency but also reduces the doses required, which can reduce costs, toxicity, and off-flavor effects. Numerous researchers have proposed several mechanisms of action for the antimicrobial activity of essential oils on microbes, such as damaging cell membranes, decreasing the proton-motive force, or interfering with key biochemical pathways (Di Pasqua et al., 2006; Swamy et al., 2016; Quinto et al., 2019; Rao et al., 2019; Tanhaeian et al., 2020). Numerous studies have shown that essential oils can be used as effective antimicrobial agents in the pharmaceutical and food industries (Diao et al., 2014; Chouhan et al., 2017; Rao et al., 2019; Tanhaeian et al., 2020). The MIC values of numerous types of essential oils against different pathogenic microorganisms are shown in Table 2.

\section{Lectins and Polypeptides}

Many plants produce antimicrobial peptides (AMPs) in response to external stresses and infections. Plant-derived AMPs are typically relatively small $(<10 \mathrm{kDa})$, cysteine-rich, cationic, and amphipathic molecules (Meneguetti et al., 2017), such as thionin, lunatusin, defensin, heveins, knottin, 2S albuminlike proteins, $\alpha$-hairpinin, hispidulin, lipid transfer protein, thionein: alpha-1-purothionin, puroindolines, cyclotides (LópezMeza et al., 2015; Tam et al., 2015; Meneguetti et al., 2017). These peptides exhibit potent antimicrobial activity toward a broad spectrum of microorganisms including bacteria, viruses, fungi, and protozoa (Franco, 2011). For example, lunatusin (7 kDa) extracted from Chinese lima bean (Phaseolus lunatus L.) exhibits antibacterial toward Bacillus megaterium, B. subtilis, Proteus vulgaris, and Mycobacterium phlei, as well as antifungal activity toward Fusarium oxysporum, Mycosphaerella arachidicola, and Botrytis cinerea (Wong and $\mathrm{Ng}, 2005)$. Hispidulin $(5.7 \mathrm{kDa}$ ) extracted from the seeds of Benincasa hispida exhibits strong antimicrobial and antifungal activities against various pathogens (Sharma et al., 2014). The most widely accepted mechanism of action of AMPs is their ability to interact with lipid components in microbial cell surfaces, resulting in membrane disruption (Yeaman and Yount, 2003; Barbosa Pelegrini et al., 2011). These cationic peptides may also exhibit antimicrobial activity through their electrostatic interactions with anionic microbial cell membranes (Barbosa Pelegrini et al., 2011). Three main mechanism of pore formation in bacterial cell membranes have been identified: transmembrane pore formation; membrane solubilization/disruption; and wormhole formation (Matsuzaki et al., 1995; Tam et al., 2015; Samriti and Biswas, 2018; Mercer et al., 2020).

\section{NANOENCAPSULATION OF PRESERVATIVES}

An effective antimicrobial compound should interact with the intended target but only have minimal interactions with nonspecific targets so as to increase its potency and reduce its deleterious effects (Mothershaw and Jaffer, 2004). The efficacy of natural antimicrobials can be altered by food matrix effects, such as phase partitioning or ingredients interactions, thereby reducing their interactions with microbes (Weiss et al., 2015). Numerous researchers have tried to overcome these effects by encapsulating the antimicrobials in edible colloidal delivery systems (Acevedo-Fani et al., 2017b; Mousavi Khaneghah et al., 2018).

Encapsulation involves trapping the antimicrobials within small particles (Abd El Kader and Abu Hashish, 2020). These particles can be designed to increase the waterdispersibility, resistance to environmental conditions, and potency of antimicrobials (Ray et al., 2016; Ferreira and Nunes, 2019). Moreover, they can be designed to mask undesirable flavors or to control the release profile of the antimicrobials (Baranwal et al., 2018; Vitiello et al., 2018). Nanotechnology is increasingly being utilized to design effective antimicrobial delivery systems by manipulating their structures on the nanoscale (Aruguete et al., 2013; Gupta et al., 2019). In general, the encapsulation and release properties of nano-enabled delivery systems depends on their composition and structure, which are governed by the ingredients and processing methods used to fabricate them (Martins et al., 2015; Akhavan et al., 2018; Taheri and Jafari, 2019). Oil-in-water nanoemulsions, which contain lipid nanoparticles dispersed in water, are currently the most commonly used nano-enabled delivery system for natural antimicrobials, because they can easily be manufactured from food-grade ingredients using common processing methods, such as mixing and homogenization (Tahmasebi et al., 2016; Lohith Kumar and Sarkar, 2018).

Different classes of antimicrobial nanoemulsions can be developed based on the type and location of the antimicrobials they contain (Figure 3). First, the oil phase itself may be inherently antimicrobial (like an essential oil). Second, a lipophilic antimicrobial (like a polyphenol) may be dissolved within an inert oil phase (like corn oil). Third, an antimicrobial emulsifier may be used to form and stabilize the nanoemulsions. Fourth, a nanoemulsion may contain a combination of different antimicrobials in different locations, which can lead to strong potency. The antimicrobial agents may move from the nanoparticles to the microbe surfaces through various mechanisms, including simple molecular diffusion, micellar diffusion, or collisions.

\section{NANOEMULSION CHARACTERISTICS}

Nanoemulsions are colloidal dispersions consisting of two immiscible fluids, with one of them being dispersed as small particles $(d<200 \mathrm{~nm})$ in the other one (Salvia-Trujillo et al., 2016). These systems are thermodynamically unstable, but can 
TABLE 2 | Minimum inhibitory concentration (MIC) of essential oils against various microorganisms.

\begin{tabular}{|c|c|c|c|c|}
\hline Essential oil & Plant source & MIC values & Target microorganisms & References \\
\hline Cinnamon & $\begin{array}{l}\text { Cinnamomum } \\
\text { zeylanicum }\end{array}$ & $\begin{array}{l}8 \mathrm{mg} / \mathrm{mL} \\
2 \mathrm{mg} / \mathrm{mL} \\
8 \mathrm{mg} / \mathrm{mL} \\
4 \mathrm{mg} / \mathrm{mL} \\
0.5 \mathrm{mg} / \mathrm{mL} \\
1 \mathrm{mg} / \mathrm{mL}\end{array}$ & $\begin{array}{l}\text { Acinetobacter } \\
\text { Klebsiella pneumoniae } \\
\text { Proteus vulgaris } \\
\text { Enterococcus faecalis } \\
\text { Staphylococcus aureus } \\
\text { Staphylococcus epidermidis }\end{array}$ & Aumeeruddy-Elalfi et al., 2015 \\
\hline Lavender & Lavandula officinalis & $\begin{array}{l}2,000 \mathrm{ppm} \\
1,000-1,200 \mathrm{ppm}\end{array}$ & $\begin{array}{l}\text { E. coli } \\
\text { S. aureus }\end{array}$ & Martucci et al., 2015 \\
\hline Oleoresin & Liquidambar formosana & $\begin{array}{l}156 \mu \mathrm{g} / \mathrm{mL} \\
156 \mu \mathrm{g} / \mathrm{mL} \\
156 \mu \mathrm{g} / \mathrm{mL} \\
78 \mu \mathrm{g} / \mathrm{mL} \\
156 \mu \mathrm{g} / \mathrm{mL} \\
313 \mu \mathrm{g} / \mathrm{mL} \\
625 \mu \mathrm{g} / \mathrm{mL}\end{array}$ & $\begin{array}{l}\text { Bacillus cereus } \\
\text { Cutibacterium acnes } \\
\text { S. aureus } \\
\text { S. epidermidis } \\
\text { Streptococcus pyogenes } \\
\text { P. aeruginosa } \\
\text { Serratia marcescens }\end{array}$ & Decarlo et al., 2020 \\
\hline Lemon bergamot & $\begin{array}{l}\text { Citrus limon } \\
\text { Citrus bergamia }\end{array}$ & $4 \%(v / v)$ & $\begin{array}{l}\text { S. aureus, E. coli } \\
\text { Aspergillus niger }\end{array}$ & Çakmak et al., 2020 \\
\hline $\begin{array}{l}\text { Frankincense } \\
\text { Myrtle } \\
\text { Thyme } \\
\text { Lemon } \\
\text { Oregano } \\
\text { Lavender }\end{array}$ & $\begin{array}{l}\text { Boswellia sacra } \\
\text { Myrtus communis } \\
\text { Thymus vulgaris } \\
\text { C. limon } \\
\text { Origanum vulgare } \\
\text { Lavandula officinalis }\end{array}$ & $0.1 \%$ to $>50 \%(\mathrm{v} / \mathrm{v})$ & $\begin{array}{l}\text { S. aureus, E. faecalis, E. coli, } \\
\text { K. pneumoniae, P. aeruginosa }\end{array}$ & Man et al., 2019 \\
\hline Betel leaf & Piper betle & $\begin{array}{l}8 \mathrm{mg} / \mathrm{mL} \\
4 \mathrm{mg} / \mathrm{mL} \\
4 \mathrm{mg} / \mathrm{mL} \\
4 \mathrm{mg} / \mathrm{mL} \\
0.5 \mathrm{mg} / \mathrm{mL} \\
0.5 \mathrm{mg} / \mathrm{mL}\end{array}$ & $\begin{array}{l}\text { Acinetobacter } \\
\text { K. pneumoniae } \\
\text { P. vulgaris } \\
\text { E. faecalis } \\
\text { S. aureus } \\
\text { S. epidermidis }\end{array}$ & Aumeeruddy-Elalfi et al., 2015 \\
\hline Willow herb & Epilobium parviflorum & $10-40 \mu \mathrm{g} / \mathrm{mL}$ & $\begin{array}{l}\text { E. faecalis, S. aureus, E. coli, } \\
\text { P. aeruginosa }\end{array}$ & Bajer et al., 2017 \\
\hline Lemongrass & Cymbopogon citratus & $\begin{array}{l}0.6 \mu \mathrm{L} / \mathrm{mL} \\
2.5 \mu \mathrm{L} / \mathrm{mL} \\
0.6 \mu \mathrm{L} / \mathrm{mL}\end{array}$ & $\begin{array}{l}\text { E. coli } \\
\text { Salmonella Typhimurium } \\
\text { S. aureus }\end{array}$ & Burt, 2004 \\
\hline Sweet marjoram & Origanum majorana & $\begin{array}{l}45.0 \mathrm{mg} / \mathrm{mL} \\
22.5 \mathrm{mg} / \mathrm{mL} \\
45.0 \mathrm{mg} / \mathrm{mL} \\
22.5 \mathrm{mg} / \mathrm{mL} \\
22.5 \mathrm{mg} / \mathrm{mL}\end{array}$ & $\begin{array}{l}\text { E. coli } \\
\text { Salmonella enterica } \\
\text { P. aeruginosa } \\
\text { B. subtilis } \\
\text { S aureus }\end{array}$ & Moumni et al., 2020 \\
\hline Tea bush & Lippia spp. & $\begin{array}{l}2.5->80 \mu \mathrm{l} / \mathrm{mL} \\
5.0->80 \mu \mathrm{l} / \mathrm{mL} \\
0.6-40 \mu \mathrm{l} / \mathrm{mL} \\
5-10 \mu \mathrm{l} / \mathrm{mL}\end{array}$ & $\begin{array}{l}\text { E. coli } \\
\text { Shigella dysenteriae } \\
\text { S. aureus } \\
\text { B. cereus }\end{array}$ & Bassole et al., 2003 \\
\hline Lantanas & Lantana xenica & $\begin{array}{l}9.1 \mathrm{mg} / \mathrm{mL} \\
9.1 \mathrm{mg} / \mathrm{mL}\end{array}$ & $\begin{array}{l}\text { Proteus mirabilis } \\
\text { B. cereus }\end{array}$ & Juliani et al., 2002 \\
\hline $\begin{array}{l}\text { Rosemary } \\
\text { Peppermint } \\
\text { Anise }\end{array}$ & $\begin{array}{l}\text { Rosmarinus officinalis } \\
\text { Mentha piperita } \\
\text { Pimpinella anisum }\end{array}$ & $\begin{array}{l}10 \mathrm{mg} / \mathrm{mL} \\
10 \mathrm{mg} / \mathrm{mL} \\
10 \mathrm{mg} / \mathrm{mL}\end{array}$ & Clostridium perfringens & Radaelli et al., 2016 \\
\hline Lemon myrtle & Backhousia citriodora & $\begin{array}{l}200 \mu \mathrm{g} / \mathrm{ml} \\
50 \mu \mathrm{g} / \mathrm{ml}\end{array}$ & $\begin{array}{l}\text { E. coli } \\
\text { S. aureus }\end{array}$ & Thielmann et al., 2019 \\
\hline
\end{tabular}


TABLE 2 | Continued

\begin{tabular}{llll}
\hline Essential oil & Plant source & MIC values & Target microorganisms \\
\hline Origanum & Thymus capitatus & $0.06-0.5 \%(\mathrm{v} / \mathrm{v})$ & Methicillin-resistant \\
Thyme & T. vulgaris & $0.06-1 \%(\mathrm{v} / \mathrm{v})$ & S. aureus \\
Tea tree & Melaleuca alternifolia & $0.12-1 \%(\mathrm{v} / \mathrm{v})$ & \\
Basil & Ocimum basilicum & $0.25-4 \%(\mathrm{v} / \mathrm{v})$ & \\
Chamomile & Matricaria chamomilla & $2->4 \%(\mathrm{v} / \mathrm{v})$ & E. coli \\
Ravintsara & Cinnamomum & $6,400 \mu \mathrm{g} / \mathrm{ml}$ & S. aureus \\
& camphora & $3,200 \mu \mathrm{g} / \mathrm{ml}$ & Vancomycin-resistant \\
Origanum & T. capitatus & $0.25-1 \%(\mathrm{v} / \mathrm{v})$ & Enterococci \\
Thyme & T. vulgaris & $0.5-2 \%(\mathrm{v} / \mathrm{v})$ & \\
Tea tree & M. alternifolia & $1-4 \%(\mathrm{v} / \mathrm{v})$ & Thielmann et al., 2019 \\
Basil & O. basilicum & $4->4 \%(\mathrm{v} / \mathrm{v})$ & Sakkas et al., 2018 \\
Chamomile & M. chamomilla & $>4 \%(\mathrm{v} / \mathrm{v})$ &
\end{tabular}

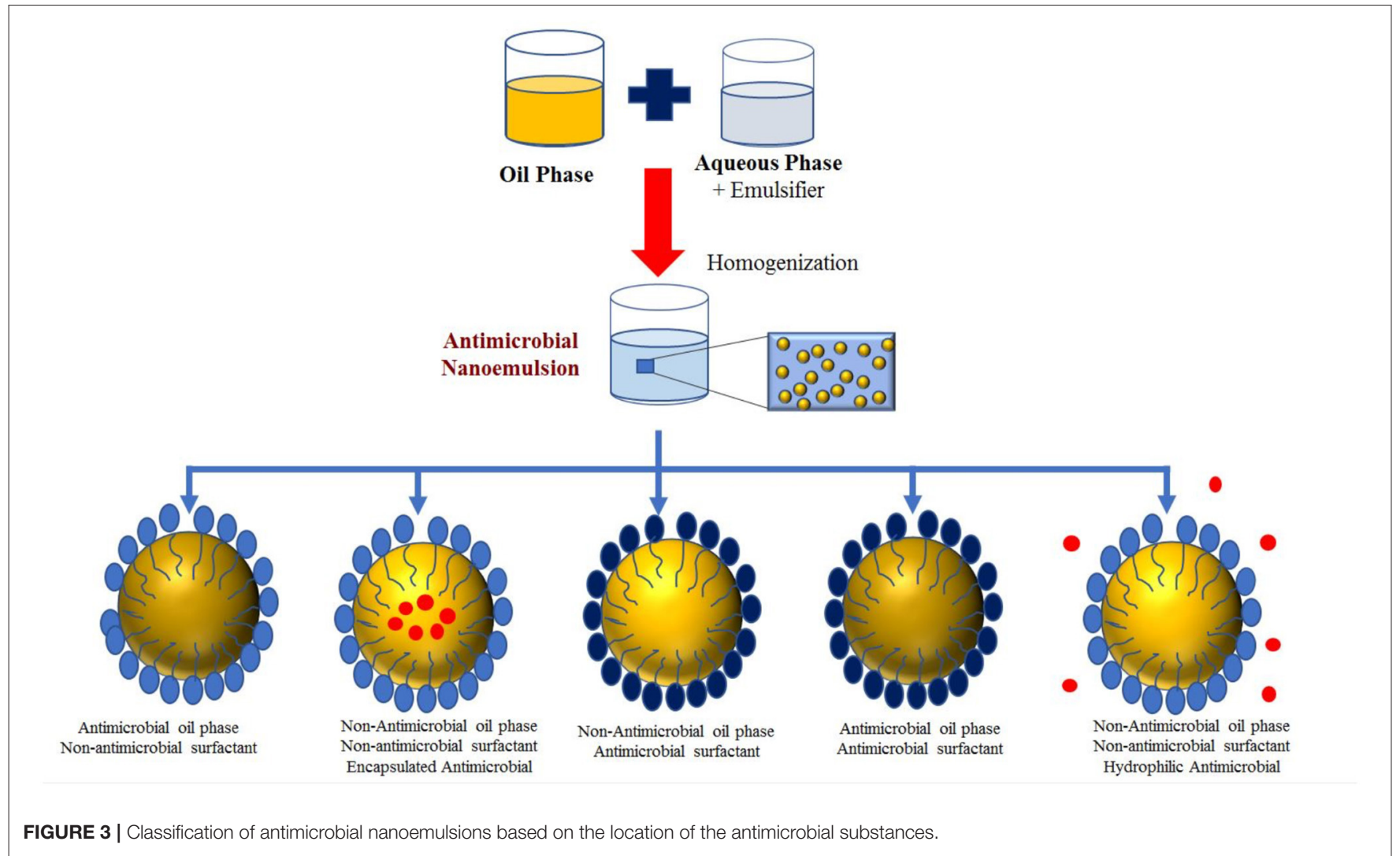

be designed to be metastable for sufficiently long periods for many commercial applications. In this section, we consider the ingredients and processing methods typically used to prepare oil-in-water nanoemulsions suitable for delivering natural plantbased antimicrobials.

\section{Ingredients}

\section{Emulsifiers}

Emulsifiers are required to facilitate the formation and to enhance the kinetic stability of nanoemulsions. Molecular emulsifiers have both hydrophilic and hydrophobic groups making them amphiphilic (Chakraborty and Dhar, 2017).
A wide range of plant-based emulsifiers are available to form nanoemulsions, including proteins (like soy or pea protein), polysaccharides (like gum arabic or modified starch), phospholipids (like soy or sunflower lecithin), and surfactants (like quillaja saponin). In addition, synthetic surfactants are often used alone or in combination with these ingredients, such as Tween and Spans. In this section, some examples of common plant-based emulsifiers for food applications are given.

Legume proteins are abundant, inexpensive, sustainable, and have low allergenicity, thus possessing many of the desirable functional traits required for food applications (Aberkane et al., 2014). Many pulses proteins exhibit good surface-active 
molecules and can act as effective emulsifiers to form and stabilize nanoemulsions (Can Karaca et al., 2015). For instance, vicilin and legumin are common globulins found in legume proteins (Donsì et al., 2010). Vicilin has been reported to be more surface active than legumin, which was attributed to its more flexible tertiary structure (Swanson, 1990). Pea, lentil, and faba bean proteins have been used as effective emulsifiers for the formulation of $10 \mathrm{wt} \%$ algae nanoemulsions using microfluidization (Gumus et al., 2017). Among these three proteins, the lentil protein showed the best efficacy in terms of the providing resistance to environmental stresses such as $\mathrm{pH}$, ionic strength, and temperature changes.

Soy protein, a rich source of essential amino acids, is collected from dehulled and deoiled soybean meal. It is a mixture of surface active globular proteins that can be used to form nanoemulsions to encapsulate bioactive agents (Chakraborty and Dhar, 2017). Soy proteins are abundant, inexpensive, biodegradable, and can exhibit good functional attributes, provided they are not denatured or aggregated prior to use. Soybean protein has been successfully used to fabricate perilla oil nanoemulsions using high-pressure homogenization (Hu et al., 2020). Similarly, sesame protein has been shown to be an effective emulsifier for forming fish oil nanoemulsions (Dey et al., 2018).

\section{Stabilizers}

The formulation of stable and efficacious antimicrobial nanoemulsions often requires the utilization of various other stabilizers, including ripening inhibitors, texture modifiers, weighting agents, interfacial stabilizers, and antioxidants. A number of the most important types of stabilizers are briefly reviewed here.

\section{Ripening Inhibitors}

Some antimicrobial nanoemulsions, especially those containing pure essential oils, are highly unstable due to a phenomenon known as Oswald ripening. This process occurs due to the net movement of oil molecules from smaller to larger oil droplets driven by differences in their curvatures. As a result, there is a net increase in the mean droplet size over time, which can accelerate creaming or coalescence. Ostwald ripening occurs particularly rapidly for polar oils (like essential oils) that have a relatively high water-solubility. This instability mechanism can be inhibited by adding hydrophobic substances that have a very low water-solubility into the oil phase of a nanoemulsion (Wooster et al., 2008). The origin of this inhibitory effect is due to entropy of mixing (McClements, 2005, 2011; Wooster et al., 2008; McClements and Rao, 2011). Typically, ripening inhibitors are highly hydrophobic substances like corn oil (Chang et al., 2012), sunflower oil (Donsì et al., 2012), medium-chain triglyceride oil (Liang et al., 2012). As an example, Ostwald ripening can be prevented in thyme oil nanoemulsions by adding a sufficiently high concentration of corn oil as a ripening inhibitor, but if too much corn oil is added it reduces the potency of the essential oil (Chang et al., 2012). Consequently, oil phase composition of nanoemulsions must be carefully formulated.

\section{Texture Modifiers: Thickening and Gelling Agents}

The stability of antimicrobial nanoemulsions can also be improved by adding texture modifiers to thicken or gel the aqueous phase, thereby inhibiting droplet movement. The most commonly used texture modifiers are polysaccharides and proteins. Thickening agents greatly increase the viscosity of aqueous solutions due to their large molecular dimensions, whereas gelling agents provide semi-solid characteristics to aqueous solutions by forming a $3 \mathrm{D}$ network of crosslinked molecules.

Carboxymethyl cellulose (CMC), a chemical derivative of cellulose is an anionic thickening agent that is widely used as a stabilizer in emulsions and nanoemulsions (Nussinovitch, 1997; Bayarri et al., 2009). It is colorless, odorless, palatable, and physiologically inert, which makes it suitable for use in fruit juices and soft drinks to inhibit gravitational separation (Mirhosseini et al., 2008; Bayarri et al., 2009). The impact of CMC on the flow behavior of food emulsions has been characterized using rheological methods (Arancibia et al., 2013). Sodium alginate has been used as a thickening agent and stabilizer in antimicrobial lemongrass oil nanoemulsions (Salvia-Trujillo et al., 2013). Pectin has also been added to oregano, thyme, mandarin, and lemongrass oil nanoemulsions as a thickening or gelling agent to improve their stability (Guerra-Rosas et al., 2016).

\section{Interfacial Stabilizers}

The stability of antimicrobial nanoemulsions can be improved using interfacial engineering approaches. In particular, electrostatic deposition methods have been used to coat oil droplets with polysaccharides, which increase the steric and electrostatic repulsion between them, thereby inhibiting aggregation. As an example, the storage stability of thymol nanoemulsions was increased by coating whey protein-coated oil droplets by chitosan hydrochloride (Li et al., 2021).

\section{Weighting Agents}

Weighting agents are added to the oil phase of nanoemulsions to inhibit gravitational separation, i.e., creaming and sedimentation (McClements, 2016). These substances are usually hydrophobic substances that have an appreciably higher density than water and can be dissolved in the oil phase prior to homogenization, such as brominated vegetable oil, ester gum, damar gum, and sucrose acetate isobutyrate. These weighting agents have all been shown to increase the creaming stability of nanoemulsions by matching the density of the oil phase to that of the water phase, thereby reducing the gravitational driving force for separation (Chanamai and McClements, 2000).

\section{Antioxidants}

Essential oils may oxidize during storage, thereby losing their antimicrobial activity. Consequently, it is often important to add natural antioxidants to inhibit their oxidation. For instance, quercetin has been reported to exhibit good antioxidant activity in nanoemulsions (Retta et al., 2012). Similarly, curcumin has been shown to reduce oxidation in nanoemulsions (Sanidad et al., 2019). 


\section{Nanoemulsion Formation}

Oil-in-water nanoemulsions are thermodynamically unstable/kinetically stable colloidal dispersions containing oil droplets with relatively small diameters, i.e., $d<200 \mathrm{~nm}$ (Salvia-Trujillo et al., 2016). They can be produced using two different approaches: (i) low-energy methods and (ii) high-energy methods (Jiang et al., 2020). Low-energy methods produce small oil droplets using the internal chemical energy of the system, With or without gentle stirring (Ren et al., 2019). In contrast, high-energy methods produce small oil droplets by applying intense disruptive forces that break up the oil and water phases e.g., microfluidizers, high-pressure homogenizers, and sonicators (Ren et al., 2019; Jiang et al., 2020). The low-energy methods require no specialized equipment, but typically require high concentrations of synthetic surfactants (Borrin et al., 2016).

\section{Low-Energy Emulsification Methods}

Low-energy methods of preparing nanoemulsions include spontaneous emulsification (SE), phase inversion composition (PIC), phase inversion temperature (PIT), and emulsion inversion point (EIP) methods (Salvia-Trujillo et al., 2016). These methods are all based on the spontaneous formation of small oil droplets when the system composition or environmental conditions are altered in a specific way (Anton et al., 2008). The size and stability of the oil droplets produced depends on the type and concentration of surfactants and oils used, which should therefore be carefully optimized (Bouchemal et al., 2004). As an example, antimicrobial black pepper oil nanoemulsions have been prepared using the PIT method with Tween 80 as a non-ionic surfactant (Vinh et al., 2020). In this case, a mixture of water $(86 \%)$, surfactant $(9.7 \%)$, and oil $(4.3 \%)$ was heated to $75^{\circ} \mathrm{C}$ for $30 \mathrm{~min}$ and then rapidly cooled to $5^{\circ} \mathrm{C}$ for $15 \mathrm{~min}$, which led to the spontaneous formation of nanoemulsions. MoraesLovison et al. (2017) produced oregano oil nanoemulsions using the PIT method, which exhibited good antimicrobial activity against Staphylococcus and E. coli. The incorporation of these nanoemulsions into chicken pâté did not change the desirable physicochemical characteristics of the product. The EIP method has been used to form nanoemulsions containing a mixture of clove and cinnamon oil, which were found to act as a good food preservative due to their antimicrobial activity (Zhang et al., 2017). In another study, Chang et al. (2013) formulated antimicrobial carvacrol oil nanoemulsions using the SE method. The same method was also used to create antimicrobial nanoemulsions from a mixture of cinnamon and coconut oils (Yildirim et al., 2017). Finally, Marei et al. (2018) showed that chitosan/citral oil nanoemulsions formulated using a low-energy method exhibited potent antimicrobial activity against Erwinia carotovora, Aspergillus niger, and Rhizopus stolonifer.

\section{High-Energy Emulsification Methods}

Industrially, nanoemulsions tend to be produced by high energy methods such as high-pressure homogenization, microfluidization, and sonication (Salvia-Trujillo et al., 2016). In sonication, an ultrasonic probe placed in a mixture of oil, water, and emulsifier is used to generate intense disruptive forces (Jafari et al., 2008). In particular, microbubbles are created within the mixture due to cavitation effects due to by the rapid pressure fluctuations caused by the high-intensity ultrasonic waves, which mix the oil and water phases together and convert large droplets into smaller ones (Modarres-Gheisari et al., 2019). High-pressure homogenization uses a pump to force a coarse emulsion through a small valve, which generates intense shear, cavitation, and turbulent forces, thereby breaking down the large droplets (Modarres-Gheisari et al., 2019). Ma et al. (2017) have used this approach to prepare curcumin loaded-nanoemulsions from various kinds of oils and emulsifiers. Microfluidizers use a pump to force a coarse emulsion through two separate channels, which are then made to impinge on each other so that the fluids collide with each other at high velocity, thereby leading to the disruption of the large oil droplets (Bai and McClements, 2016).

High-intensity methods have been used to create various kinds of antimicrobial nanoemulsions. Sonication has been used to create antimicrobial nanoemulsions from Cleome viscosa essential oil and Tween 80, which were shown to be effective against Streptococcus pyogenes, S. aureus, E. coli, K. pneumoniae, and $P$. aeruginosa (Krishnamoorthy et al., 2018). Sonication has also been used to produce chitosan/eugenol oil nanoemulsions that exhibited strong antimicrobial activity (Shao et al., 2018). The same method has also been used to prepare citral oil nanoemulsions that were shown to exhibit potent antimicrobial effects against several bacterial strains (Lu et al., 2018). Sonication has also been used to form antimicrobial nanoemulsions from lemon myrtle and anise myrtle essential oils (Nirmal et al., 2018), geraniol and carvacrol (Syed and Sarkar, 2018), and thyme oil (Moghimi et al., 2016).

High-pressure homogenization has been used to prepare black pepper oil nanoemulsions that exhibited antimicrobial efficacy against bacterial pathogens in aquaculture (Swathy et al., 2018). Similarly, black pepper and cinnamon oil nanoemulsions produced by the same method have been shown to exhibit an antimicrobial effect against disease-related pathogens and food spoilage bacteria (Jiménez et al., 2018). Microfluidization has been used to produce antimicrobial carvacrol nanoemulsions using a natural surfactant (quillaja saponin), leading to all natural plant-based formulations (Ryu et al., 2018). A simple highshear mixer has been used to form eugenol and thymol oil nanoemulsions stabilized by a mixture of food-grade surfactants (lauric arginate and lecithin), which exhibited good antibacterial effects against L. monocytogenes and E. coli (Ma et al., 2016).

\section{Microencapsulation}

Spray-drying can be used to convert a nanoemulsion into a fine powder, which improves its handling, storage, transport, and stability (Gharsallaoui et al., 2007). A nanoemulsion is first formed in a fluid state and then passed through a nozzle that sprays it into a hot chamber, which leads to rapid evaporation of the water phase. Nielsen et al. (2016) showed that spray drying could also be used to convert isoeugenol oil nanoemulsions into powders, which had high essential oil loading capacities and exhibited good antimicrobial activity against both Gram-positive and Gram-negative bacteria. The same authors showed that these nanoemulsions could disrupt the biofilms formed by pathogenic bacteria (Nielsen et al., 2017). Spray drying has also been used to 
convert eugenol nanoemulsions into powders (Talón et al., 2019). The powders produced had high encapsulation efficiencies (9598\%) and exhibited strong antibacterial activity against E. coli when dispersed in water.

\section{Droplet Properties}

The physicochemical properties, stability, and efficacy of antimicrobial nanoemulsions can be altered by varying oil droplet properties (Buranasuksombat et al., 2011), such as their composition, concentration, interfacial properties, and physical state. For instance, reducing the droplet size reduces the opacity and increases the resistance to gravitational separation and aggregation of nanoemulsions. In addition, the droplet characteristics impact how the oil droplets interact with the surfaces of microbes. For instance, the droplets can be made to stick to the surfaces of the microbes using electrostatic effects: positively charged oil droplets will be attracted to negatively charged microbe surfaces, thereby bringing them into close proximity. Consequently, it is important to carefully tailor the properties of the oil droplets for particular applications.

\section{Physicochemical Properties and Stability}

Nanoemulsions are thermodynamically unstable systems that breakdown by different physicochemical mechanisms. The main destabilization mechanisms of nanoemulsions are gravitational separation (creaming/sedimentation), flocculation, coalescence, and Ostwald ripening, which have been reviewed in detail elsewhere (McClements, 2005).

\section{Gravitational Separation}

A density difference normally exists between the oil and water phases in nanoemulsions, which promotes phase separation through gravitational forces. The density of oil droplets tends to be lower than that of water, thereby causing them to move upward due to creaming (Pathak, 2017). In the rare cases where the oil droplet density is higher than that of water, the droplets move downwards due to sedimentation. The rate of gravitational separation is governed by Stokes' Law, which states that the rate is proportional to the density different between the phases, the square of the droplet size, and the inverse of the continuous phase viscosity. Thus, nanoemulsion stability can be increased by reducing the particle size and density contrast, and increasing the aqueous phase viscosity.

\footnotetext{
Aggregation

Aggregation occurs when the attractive forces (usually van der Waals, hydrophobic, depletion, and bridging attraction) acting between the droplets outweigh the repulsive forces (usually steric and electrostatic repulsion) (McClements, 2005). It is therefore important to identify the dominant colloidal interactions present within nanoemulsions and then reduce the attractive forces and/or increase the repulsive forces by changing the composition or structure of the system. Droplet aggregation may occur due to coalescence or flocculation depending on the nature of the forces involved. Coalescence involves the merging together of smaller droplets into larger ones. Flocculation involves two or more droplets coming together and forming clusters.
}

Often, flocculation is a precursor for coalescence since it brings the droplets close together for prolonged periods. In dilute nanoemulsions, droplet aggregation usually accelerates creaming or sedimentation due to the increase in particle size. Eventually, coalescence may lead to the formation of a separate layer of oil on top of the nanoemulsion ("oiling off"). In concentrated nanoemulsions, droplet flocculation can actually inhibit gravitational separation and lead to the formation of a semi-solid texture because of the formation of a 3D particle network that extends throughout the sample.

\section{Ostwald Ripening}

This mechanism leads to a net increase in droplet size due to diffusion of oil molecules from small to large droplets driven by differences in droplet curvature (McClements, 2005). The rate of Ostwald ripening increases as the water-solubility of the oil phase increases, and is therefore more important for polar oils, such as the essential oils often used as plant-based antimicrobial agents. Consequently, it is important to prevent this mechanism by adding ripening inhibitors (see section Ripening Inhibitors). These ripening inhibitors are strongly hydrophobic molecules that have a very low solubility in water. As a result, they cannot move from one droplet to another very quickly, if at all. Thus, as Ostwald ripening proceeds there is a difference in composition between the small and large oil droplets, which generates an osmotic stress that opposes further exchange of oil molecules between the droplets due to an entropy of mixing effect. Eventually, droplet growth due to Ostwald ripening is therefore inhibited.

\section{DELIVERY OF PLANT ANTIMICROBIALS USING NANOEMULSIONS}

\section{Application in Agriculture}

Pesticides are used to improve the quality and yield of crops by reducing their susceptibility to microorganisms, insects, herbivores, and other invasive species (weeds) (Zhang et al., 2015; McClements, 2020). These pesticides may be fungicides, nematicides, insecticides, and herbicides depending on their target (Feng et al., 2018). The use of synthetic chemical pesticides in excessive quantity can damage the environment and pose a risk to human health. Consequently, there is interest in developing natural plant-based pesticides that are less toxic. The hydrophobic nature of many natural pesticides, however, means they have a low water-solubility, and so it is difficult to get the required quantity to the site of action. They can sometimes be converted into solids, but powdered or granular forms of these pesticides often have limitations due to their large particle size, poor adhesion properties, and low solubility characteristics (Mulqueen, 2003).

For these reasons, there is growing interest in the use of colloidal forms of plant-based pesticides, such as antimicrobial nanoemulsions (McClements, 2020). These nanoemulsions should be carefully designed to protect the antimicrobials from evaporation or chemical degradation during storage and application, while still remaining efficacious against the target spoilage or pathogenic microorganisms. The use of 
nanoemulsions can improve the potency and/or reduce the required dose of plant-based antimicrobials, which may reduce their potential toxicity (Ibrahim, 2020). For example, insecticidal nanoemulsions have been formulated from a hexane-soluble fraction of Manilkara subsericea for use against an important cotton pest (Dysdercus peruvianus) (Fernandes et al., 2014). This study showed that the nanoemulsions were effective against the pests, while also having a lower impact on the environment and on non-targeted organisms. Nanoemulsions containing neem oil were shown to be effective against two insects, the rice weevil (Sitophilus oryzae) and the red flour beetle (Tribolium castaneum) that infect important commercial crops (Choupanian et al., 2017). The droplet size of the nanoemulsions influenced the mortality rate, with smaller particle sizes being more effective. Antimicrobial nanoemulsions formulated from Mentha piperita oil have been shown to be effective insecticides against cotton aphids (Heydari et al., 2020). Nanoencapsulated Melissa officinalis L. oil was reported to exhibit strong insecticidal activity against Tribolium castaneum Herbst and could be used as an ecofriendly and safe plant-based pesticide (Upadhyay et al., 2019). These studies suggest that plant-based nanopesticides could be a viable alternative to conventional chemical pesticides.

\section{Application in Foods}

There has been a growing demand for healthier and safer food products by consumers, which has led manufacturers to reformulate their products with more natural ingredients (Das et al., 2019). However, these ingredients must still exhibit the required functional attributes. Foods with high moisture contents, nutrient levels, and $\mathrm{pH}$ values tend to spoil easily and cannot normally be stored for long periods. Post-harvest handling and processing operations often increase the chances of microbial contamination and growth, thereby reducing food quality and shelf-life (Hygreeva and Pandey, 2016; Das et al., 2019). Food-borne pathogens such as Clostridium botulinum, Salmonella, S. aureus, Campylobacter jejuni, B. cereus, $L$. monocytogenes, Cryptosporidium, and E. coli O157:H7 may cause foodborne illnesses (Arshad and Batool, 2017). Natural antimicrobials are therefore being developed to reduce microbial contamination and prolong the shelf-life of these products (Barros-Velazquez, 2016). A number of natural antimicrobial agents have been shown to be promising alternatives to synthetic ones (Donsì and Ferrari, 2016). Again, many of these antimicrobial agents are hydrophobic substances that only have limited water-solubility and have poor chemical stability. These problems can often be overcome by using well-designed nanoemulsions as delivery systems.

Antimicrobial nanoemulsions have been reported to be able to suppress microbial growth, maintain quality, and prolong the shelf-life of many foods (Salvia-Trujillo et al., 2015; Das et al., 2020a). These systems have been shown to be effective against both Gram-positive and Gram-negative bacteria (Sutcliffe et al., 2008; Ferreira et al., 2010), which has been attributed to their ability to damage the structure and function of microbial cell walls (Jones et al., 1997; Baker et al., 2003) or to prevent biofilm formation by interrupting intercellular signaling (Joe et al., 2015). The strong antimicrobial activity of nano-emulsified version of plant-based antimicrobials like essential oils and other phytochemicals, such as carvacrol, cinnamaldehyde, thymol, limonene, eugenol, and curcumin, have been demonstrated against a broad spectrum of spoilage pathogens in various food systems (Donsì et al., 2012; Salvia-Trujillo et al., 2016; Quinto et al., 2019). Representative examples of studies on plant-based antimicrobial nanoemulsions are summarized in Table 3.

\section{Meat and Meat Products}

Some of the major species of microorganisms contaminating meat and meat products are Salmonella, S. aureus, C. jejuni, E. coli O157:H7, and L. monocytogenes, with the latter being the most commonly detected (Kaur and Kaur, 2020). Numerous studies have shown that plant-based antimicrobial nanoemulsions have promise to control microbial growth in these products. These nanoemulsions may be applied to meat and fish products as additives, dips, sprays, coatings, or films (Wu et al., 2016b; Pabast et al., 2018).

Oregano oil nanoemulsions have been incorporated into chicken pate to significantly inhibit the growth of $S$. aureus and E. coli, thereby extending the shelf-life (Moraes-Lovison et al., 2017). Balta et al. (2017) reported that geraniol- and linalool-loaded nanoemulsions inhibited the growth of $E$. coli K12, Listeria innocua, and Pseudomonas lundensis in a simulated meat system. Ghaderi-Ghahfarokhi et al. (2017) reported a significant decrease in S. aureus, Enterobacteriaceae, yeast, and mold when beef patties were treated with chitosan/cinnamon oil nanoemulsions. Curcumin-loaded nanoemulsions containing pectin-coated oil droplets were shown to inhibit the growth of psychrophilic bacteria, yeast, and mold in refrigerated chicken fillets (Abdou et al., 2018). Microbial growth has also been inhibited in refrigerated Turkey meat treated with essential oil nanoemulsions containing Zataria Boiss (ZEO) and Bunium persicum Boiss (BEO), as well as chitosan (Keykhosravy et al., 2020). These authors reported that $1 \%$ ZEO nanoemulsions exhibited strong inhibitory effects on total viable bacteria, total psychrophilic bacteria, Pseudomonas spp., Enterobacteriaceae, lactic acid bacteria, S. Enteritidis, and L. monocytogenes. As a result, the shelf-life increased from 6 days in the untreated meat to 15-18 days in the nanoemulsion-treated meat. As well as improving the safety and shelf-life of meat products, plant-based antimicrobial nanoemulsions have also been shown to improve their physicochemical and sensory properties (Das et al., 2020a).

Plant-based antimicrobial nanoemulsions must be carefully formulated for application in meat products. Numerous studies have reported that the efficacy of plant-based antimicrobials may be reduced in meat due to their interaction with meat components, such as fat droplets and proteins (Das et al., 2020a; Kaur and Kaur, 2020).

\section{Milk and Milk Products}

The dairy industry also faces challenges with spoilage and pathogenic organisms (Boor et al., 2017). As a result, they may also benefit from the utilization of antimicrobial nanoemulsions (Kaur and Kaur, 2020). Thymol oil nanoemulsions stabilized by casein are effective antimicrobial agents in milk products (Pan et al., 2014). Thymol nanoemulsions stabilized by a 
TABLE 3 | Delivery of various kinds of plant-based antimicrobials using nanoemulsions in different food systems.

\begin{tabular}{|c|c|c|c|c|c|}
\hline $\begin{array}{l}\text { Plant } \\
\text { antimicrobial }\end{array}$ & Nanoemulsion type & $\begin{array}{l}\text { Method of } \\
\text { nanoemulsion } \\
\text { preparation }\end{array}$ & Food system & Key findings & References \\
\hline Oregano oil & $\begin{array}{l}\text { Nanoemulsions containing } \\
\text { mandarin fiber }\end{array}$ & Microfluidization & Low-fat cheese & $\begin{array}{l}\text { - Inhibited Staphylococcus aureus } \\
\text { population from } 6.0 \text { to } 4.6 \text { log CFU/g } \\
\text { after } 15 \text { days. } \\
\text { - Decreased psychrophilic bacteria, } \\
\text { molds and yeasts growth } \\
\text { during storage }\end{array}$ & $\begin{array}{l}\text { Artiga-Artigas et al., } \\
2017\end{array}$ \\
\hline $\begin{array}{l}\text { Satureja } \\
\text { khuzestanica oils }\end{array}$ & $\begin{array}{l}\text { Chitosan coatings loaded } \\
\text { with free or } \\
\text { nano-encapsulated oil }\end{array}$ & $\begin{array}{l}\text { Thin-film } \\
\text { hydration-sonication } \\
\text { method }\end{array}$ & Lamb meat & $\begin{array}{l}\text { - Effectively retarded microbial growth } \\
\text { and chemical spoilage } \\
\text { - Extended the shelf-life of lamb meat by } \\
\text { maintaining prolonged antimicrobial } \\
\text { and antioxidant activity } \\
\text { - Improved sensory attributes }\end{array}$ & Pabast et al., 2018 \\
\hline $\begin{array}{l}\text { Zataria multiflora } \\
\text { Boiss and Bunium } \\
\text { persicum Boiss } \\
\text { oils }\end{array}$ & $\begin{array}{l}\text { Nanoemulsions loaded into } \\
\text { chitosan-based coatings }\end{array}$ & Sonication & Turkey meat & $\begin{array}{l}\text { - Reduced total viable bacteria, total } \\
\text { psychrophilic, Pseudomonas spp., } \\
\text { Enterobacteriaceae, lactic acid } \\
\text { bacteria, and yeast and mold count } \\
\text { than control samples } \\
\text { - Increased the shelf-life significantly of } \\
\text { treated samples up to 15-18 days }\end{array}$ & $\begin{array}{l}\text { Keykhosravy et al., } \\
2020\end{array}$ \\
\hline Oregano oil & $\begin{array}{l}\text { Nanoemulsions (5-7 g } \\
\text { oil/100 g nanoemulsion) }\end{array}$ & $\begin{array}{l}\text { Phase inversion } \\
\text { temperature method }\end{array}$ & Chicken pate & $\begin{array}{l}\text { - Exhibited good antibacterial action } \\
\text { against } S \text {. aureus and Escherichia coli } \\
\text { with minimum inhibitory concentration } \\
0.56 \text { and } 0.60 \mathrm{mg} / \mathrm{ml} \text {, respectively } \\
\text { - Improved shelf-life by controlling the } \\
\text { microbial growth }\end{array}$ & $\begin{array}{l}\text { Moraes-Lovison et al., } \\
2017\end{array}$ \\
\hline Sunflower oil & $\begin{array}{l}\text { Nanoemulsions based on } \\
\text { sunflower oil }\end{array}$ & Sonication & $\begin{array}{l}\text { Farmed sea bass } \\
\text { and gilthead sea } \\
\text { bream fillets }\end{array}$ & $\begin{array}{l}\text { - Inhibited the bacterial growth } \\
\text { - Prolonged the shelf-life as well as } \\
\text { improved the quality of fillets } \\
\text { during storage }\end{array}$ & Yazgan et al., 2017 \\
\hline $\begin{array}{l}\text { Thymol } \\
\text { nanoemulsions }\end{array}$ & $\begin{array}{l}\text { Nanoemulsions stabilized by } \\
\text { gelatin and lecithin }\end{array}$ & $\begin{array}{l}\text { Homogenization and } \\
\text { Sonication }\end{array}$ & $\begin{array}{l}\text { Milk and } \\
\text { cantaloupe juice }\end{array}$ & $\begin{array}{l}\text { - Inhibited the Listeria monocytogenes } \\
\text { by } 5 \text { and } 3 \text { log CFU/mL in } 2 \% \text { reduced } \\
\text { fat and full fat milk after } 48 \mathrm{~h} \text {, } \\
\text { respectively } \\
\text { - Both thymol emulsions more effective } \\
\text { than free thymol against } L \text {. } \\
\text { monocytogenes and E. coli } \mathrm{O} 157: \mathrm{H} 7 \text { in } \\
\text { milk } \\
\text { - Could be used as novel antimicrobial } \\
\text { preservatives to enhance the } \\
\text { food safety }\end{array}$ & Xue et al., 2017 \\
\hline Thyme oil & Nanoemulsions & Sonication & Fish & $\begin{array}{l}\text { - Effectively inhibited the food-borne } \\
\text { pathogens by damaging bacterial cell } \\
\text { membranes } \\
\text { - Nanoemulsion formulation increased } \\
\text { the antibacterial activity of thyme } \\
\text { - Have potential as an alternative } \\
\text { antimicrobial agent in processed or } \\
\text { packaged fish or food products. }\end{array}$ & Ozogul et al., 2020 \\
\hline $\begin{array}{l}\text { Geraniol and } \\
\text { linalool }\end{array}$ & $\begin{array}{l}\text { Nanoemulsions prepared } \\
\text { with geraniol or linalool }\end{array}$ & Sonication & Meat & $\begin{array}{l}\text { - Significantly reduced E. coli K12, and } \\
\text { Listeria innocua counts } \\
\text { - Could be used as promising } \\
\text { antimicrobial system for food } \\
\text { preservation and food safety }\end{array}$ & Balta et al., 2017 \\
\hline $\begin{array}{l}\text { Cinnamon, garlic } \\
\text { or sunflower oil }\end{array}$ & $\begin{array}{l}\text { Nanoemulsions loaded into } \\
\text { pectin-based coatings }\end{array}$ & $\begin{array}{l}\text { Emulsion inversion } \\
\text { point method }\end{array}$ & Chicken fillets & $\begin{array}{l}\text { - Coating with nanomeulsion reduced } \\
\text { the total plate count, psychrophilic } \\
\text { bacteria, yeast, and mold growth } \\
\text { - Effectively checked the deterioration of } \\
\text { fillets texture } \\
\text { - Prolonged shelf-life up to } 12 \text { days }\end{array}$ & Abdou et al., 2018 \\
\hline
\end{tabular}


TABLE 3 | Continued

\begin{tabular}{|c|c|c|c|c|c|}
\hline $\begin{array}{l}\text { Plant } \\
\text { antimicrobial }\end{array}$ & Nanoemulsion type & $\begin{array}{l}\text { Method of } \\
\text { nanoemulsion } \\
\text { preparation }\end{array}$ & Food system & Key findings & References \\
\hline Citrus oil & $\begin{array}{l}\text { Nanoemulsions containing } \\
\text { chitosan }\end{array}$ & $\begin{array}{l}\text { Emulsion-ionic } \\
\text { gelation technique }\end{array}$ & $\begin{array}{l}\text { Fresh silvery } \\
\text { pomfret fillets }\end{array}$ & $\begin{array}{l}\text { - Successfully checked the microbial } \\
\text { growth } \\
\text { - Reduced the biochemical changes } \\
\text { - Extended shelf-life from } 12 \text { to } 16 \text { days } \\
\text { - Have potential as an effective } \\
\text { preservative for marine fish }\end{array}$ & Wu et al., $2016 a$ \\
\hline Thymol & $\begin{array}{l}\text { Thymus nanoemulsion } \\
\text { (NE-Thy) loaded into quinoa } \\
\text { protein-chitosan films }\end{array}$ & $\begin{array}{l}\text { Spontaneous } \\
\text { emulsification (SE) } \\
\text { method and/or } \\
\text { Sonication }\end{array}$ & Cherry tomatoes & $\begin{array}{l}\text { - NE-Thy prepared with SE exhibited } \\
\text { antifungal activity against Botrytis } \\
\text { cinerea } \\
\text { - The edible coating of NE-SE } \\
\text { incorporated quinoa protein-chitosan } \\
\text { film inhibited B. cinerea growth on } \\
\text { cherry tomatoes } \\
\text { - Can be used as edible antifungal } \\
\text { bioactive film for improving } \\
\text { fruit shelf-life }\end{array}$ & Robledo et al., 2018 \\
\hline $\begin{array}{l}\text { Rosemary, } \\
\text { cinnamon, and } \\
\text { oregano oils }\end{array}$ & $\begin{array}{l}\text { Nanoemulsions stabilized by } \\
\text { Tween } 80\end{array}$ & Sonication & Fresh celery & $\begin{array}{l}\text { - Reduction in bacterial count in celery } \\
\text { - Inhibited } E \text {. coli and } L \text {. } \\
\text { monocytogenes growth }\end{array}$ & $\begin{array}{l}\text { Dávila-Rodríguez et al., } \\
2019\end{array}$ \\
\hline Ginger oil & $\begin{array}{l}\text { Nanoemulsions loaded into } \\
\text { caseinate coatings }\end{array}$ & Sonication & $\begin{array}{l}\text { Fresh chicken } \\
\text { breast fillet }\end{array}$ & $\begin{array}{l}\text { - Inhibited growth of } L \text {. monocytogenes } \\
\text { and S. Typhimurium } \\
\text { - Reduction in total aerobic psychrophilic } \\
\text { bacterial, yeasts and molds in chicken } \\
\text { fillet during refrigeration } \\
\text { - Increased shelf-life of chicken } \\
\text { breast fillets }\end{array}$ & Noori et al., 2018 \\
\hline Star anise oil & $\begin{array}{l}\text { Nanoemulsions loaded into } \\
\text { soy protein-based coating }\end{array}$ & Sonication & $\begin{array}{l}\text { Yao meat } \\
\text { products }\end{array}$ & $\begin{array}{l}\text { - Coatings improved total volatile basic } \\
\text { nitrogen and pH significantly } \\
\text { - Coatings inhibited bacterial growth } \\
\text { during storage at } 4^{\circ} \mathrm{C} \\
\text { - Coatings improved odor, color and } \\
\text { sensory acceptability } \\
\text { - Extended shelf-life of Yao meat } \\
\text { products up to } 16 \text { days }\end{array}$ & Liu Q. et al., 2020 \\
\hline
\end{tabular}


TABLE 3 | Continued

\begin{tabular}{|c|c|c|c|c|c|}
\hline $\begin{array}{l}\text { Plant } \\
\text { antimicrobial }\end{array}$ & Nanoemulsion type & $\begin{array}{l}\text { Method of } \\
\text { nanoemulsion } \\
\text { preparation }\end{array}$ & Food system & Key findings & References \\
\hline Lemongrass oil & $\begin{array}{l}\text { Nanoemulsions loaded into } \\
\text { alginate-based films }\end{array}$ & Microfluidization & $\begin{array}{l}\text { Fresh-cut Fuji } \\
\text { apples }\end{array}$ & $\begin{array}{l}\text { - Strong inhibition of } E \text {. coli and } \\
\text { diminished growth of psychrophilic } \\
\text { bacteria during storage } \\
\text { - Inhibited the habitat microbes of } \\
\text { fresh-cut Fuji apples during } 2 \text { weeks } \\
\text { of storage }\end{array}$ & $\begin{array}{l}\text { Salvia-Trujillo et al., } \\
2015\end{array}$ \\
\hline Mandarin oil & $\begin{array}{l}\text { Nanoemulsions loaded into } \\
\text { chitosan-based coating }\end{array}$ & $\begin{array}{l}\text { High pressure } \\
\text { homogenization }\end{array}$ & $\begin{array}{l}\text { Fresh green } \\
\text { beans }\end{array}$ & $\begin{array}{l}\text { - Synergistic antimicrobial effect of } \\
\text { bioactive coating and } \gamma \text {-irradiation } \\
\text { observed during storage } \\
\text { - Bioactive coating along with UV-C } \\
\text { treatment reduced } L \text {. innocua } \\
\text { population without affecting the } \\
\text { firmness and color of green beans } \\
\text { during storage }\end{array}$ & Severino et al., 2014 \\
\hline Carvacrol & $\begin{array}{l}\text { Nanoemulsions stabilized by } \\
\text { Tween } 80\end{array}$ & $\begin{array}{l}\text { High pressure } \\
\text { homogenization, } \\
\text { sonication }\end{array}$ & $\begin{array}{l}\text { Shredded } \\
\text { cabbages }\end{array}$ & $\begin{array}{l}\text { - Carvacrol nanoemulsion inhibited } \\
\text { growth of E. coli and Pichia pastoris } \\
\text { - Carvacrol nanoemulsion had strongest } \\
\text { effect in reducing aerobic } \\
\text { psychrotrophic and mesophilic bacteria } \\
\text { on shredded cabbage } \\
\text { - Antimicrobial effect of the treatment } \\
\text { solution lasted for } 2 \text { days }\end{array}$ & Sow et al., 2017 \\
\hline $\begin{array}{l}\text { Zataria multiflora } \\
\text { Boiss oil (ZEO) }\end{array}$ & $\begin{array}{l}\text { Nanoemulsions loaded into } \\
\text { alginate-based films }\end{array}$ & Sonication & Fresh trout & $\begin{array}{l}\text { - Reduced ( } 1 \% \text { w/v ZEO) total viable, } \\
\text { hydrogen sulfide-producing bacteria, } \\
\text { total psychrophilic, and } \\
\text { Enterobacteriaceae count } \\
\text { - All the treatment types significantly } \\
\text { reduced the microbial population in } \\
\text { fresh trout fillets during storage for } 16 \\
\text { days at } 4{ }^{\circ} \mathrm{C}\end{array}$ & Khanzadi et al., 2020 \\
\hline $\begin{array}{l}\text { Curcumin, gallic } \\
\text { acid, quercetin }\end{array}$ & $\begin{array}{l}\text { Nanoemulsions loaded into } \\
\text { gelatin-based films }\end{array}$ & $\begin{array}{l}\text { High pressure } \\
\text { homogenization }\end{array}$ & Fresh broiler meat & $\begin{array}{l}\text { - Curcumin loaded gelatin films inhibited } \\
\text { S. Typhimurium and E. coli growth } \\
\text { - Prolonged shelf-life of meat for about } \\
17 \text { days in contrast to } 10 \text { days } \\
\text { for control }\end{array}$ & Khan et al., 2020 \\
\hline Mustard oil & $\begin{array}{l}\text { Nanoemulsions stabilized by } \\
\text { Tween } 80\end{array}$ & Sonication & Turkey meat & $\begin{array}{l}\text { - Reduced molds, yeast, total } \\
\text { psychrotrophic and mesophilic bacteria } \\
\text { during storage } \\
\text { - Shelf life of Turkey meat was increased } \\
\text { to } 10-15 \text { days } \\
\text { - Improved sensory attributes, especially } \\
\text { odor and overall shelf-life of meat } \\
\text { during storage at } 4^{\circ} \mathrm{C}\end{array}$ & Milani et al., 2020 \\
\hline $\begin{array}{l}\text { Ferulago angulata } \\
\text { oil }\end{array}$ & $\begin{array}{l}\text { Nanoemulsion-loaded } \\
\text { chitosan-based coating }\end{array}$ & Sonication & $\begin{array}{l}\text { Rainbow trout } \\
\text { fillets }\end{array}$ & $\begin{array}{l}\text { - Improved antimicrobial activity against } \\
\text { Shewanella putrefaciens and } \\
\text { Pseudomonas fluorescens } \\
\text { - Offered better color, texture and overall } \\
\text { acceptability in treated samples } \\
\text { - Coating @ } 3 \% \text { successfully retarded } \\
\text { the bacterial growth and improved } \\
\text { shelf-life of fillets in rainbow trout fillets }\end{array}$ & Shokri et al., 2020 \\
\hline $\begin{array}{l}\text { Ziziphora } \\
\text { clinopodioides } \\
\text { essential oil } \\
\text { (ZCEO) }\end{array}$ & $\begin{array}{l}\text { Nanoemulsion loaded } \\
\text { chitosan-based coating }\end{array}$ & Sonication & Fresh beef & $\begin{array}{l}\text { - Nanoemulsion of chitosan-ZCEO-nisin } \\
\text { significantly inhibited the growth of } E \text {. } \\
\text { coli O157:H7 in beef samples than } \\
\text { control } \\
\text { - Effective in controlling pathogenic } \\
\text { bacteria in beef during storage }\end{array}$ & Khanzadi et al., 2019 \\
\hline
\end{tabular}


mixture of gelatin and lecithin have been shown to exhibit strong antibacterial activity against L. monocytogenes and E. coli O157:H7 in milk and cantaloupe juice (Xue et al., 2017). In some studies, the fat level in dairy products has been shown to influence the antibacterial activity of nanoemulsions. For instance, a higher inhibition of L. monocytogenes was reported in reduced fat milk (5 $\log \mathrm{CFU} / \mathrm{ml}$ ) than in full fat milk (3 $\log \mathrm{CFU} / \mathrm{ml}$ ) after $48 \mathrm{~h}$ storage (Xue et al., 2017). This effect can be attributed to partitioning of more of the hydrophobic antimicrobial agents into the milk fat globules in the full fat milk.

Nanoemulsion-based antimicrobial edible coatings prepared from oregano oil were shown to extend the shelf-life of low-fat cheese by inhibiting the growth of bacteria, molds and yeasts (Artiga-Artigas et al., 2017). In another study, encapsulation of basil (O. basilicum), mint (M. piperita), sea buckthorn (Hippophae rhamnoides), and fennel (Foeniculum vulgare) oils in sodium alginate hydrogels improved the quality characteristics and shelf-life of yogurt, which was attributed to their antimicrobial and antioxidant effects (Constantinescu et al., 2019).

\section{Fish and Fish Products}

In a recent study, thyme oil nanoemulsions were shown to exhibit antimicrobial activity against various food-borne pathogens (S. Paratyphi A, S. aureus, K. pneumoniae, and E. faecalis) and spoilage bacteria (Pseudomonas luteola, Photobacterium damselae, Vibrio vulnificus, E. faecalis, Serratia liquefaciens, and Proteus mirabilis) associated with fish and fish products (Ozogul et al., 2020). The antimicrobial activity of these nanoemulsions was attributed to their ability to damage the bacterial cell membranes. Similarly, sage oil nanoemulsions were shown to exhibit strong antimicrobial activity against foodborne pathogens and spoilage organisms, such as E. faecalis, $K$. pneumoniae, S. Paratyphi A, and S. aureus, with MIC values in the range $6.25-12.5 \mathrm{mg} / \mathrm{ml}$ (Yazgan, 2020). In another study, Joe et al. (2012) reported a significant reduction in heterotrophic and lactic acid bacteria populations, and an extension in shelflife, for fish steaks treated with sunflower oil nanoemulsions. Similarly, sea bream and sea bass fillets treated with sunflower oil nanoemulsions had a lower microbial load and longer shelflife than control samples during refrigerated storage (Yazgan et al., 2017). These studies show the potential of plant-based antimicrobial nanoemulsions as preservatives to improve the safety, quality, and shelf-life of fish products (Acevedo-Fani et al., 2017a).

\section{Fruits and Vegetables}

Fresh or only minimally processed fruits and vegetables are linked to foodborne diseases because microbial contaminants may be present. Numerous studies have shown that plantbased antimicrobial nanoemulsions can be used to improve the quality and safety of fruits and vegetables (Prakash et al., 2018). For instance, chitosan-based edible coatings containing mandarin oil nanoemulsions exhibited antimicrobial activity against L. innocua in green beans (Severino et al., 2014). Similarly, thymol nanoemulsions inhibited the growth of molds (B. cinerea) on refrigerated tomatoes (Robledo et al., 2018). In another study, edible coatings containing lemon oil nanoemulsions improved the safety and quality of freshly cut Fuji apples (Salvia-Trujillo et al., 2015), which was attributed to their ability to inhibit microbial growth. Oregano oil nanoemulsions have been reported to reduce the growth of S. Typhimurium, and E. coli $\mathrm{O} 157: \mathrm{H} 7$ on fresh lettuce by $3.4,2.3$, and $3.1 \mathrm{log}$ CFU/g, respectively (Bhargava et al., 2015). Similarly, geranioland carvacrol-loaded nanoemulsions significantly inhibited the growth of Gram-positive bacteria (B. cereus) and Gram-negative bacteria (E. coli) (Syed and Sarkar, 2018). These results highlight the potential of plant-based nanoemulsions to improve the quality, safety, and shelf-life of minimally processed or fresh fruits and vegetables.

\section{Cereals and Cereal-Based Products}

Both raw and processed cereal-based products are prone to spoilage microorganisms, such as bacteria, yeast, and mold. This spoilage reduces the quality and safety of cereal products and causes food safety concerns. There have only been a few studies on the use of nanoemulsions to improve the efficacy of plant-based antimicrobial agents in cereal-based products (Kaur and Kaur, 2020). Methylcellulose films loaded with clove bud oil (S. aromaticum) or oregano oil (Origanum vulgare) nanoemulsions have been shown to inhibit the growth of yeasts and molds in sliced bread (Otoni et al., 2014). The antimicrobial activity of these systems increased as their droplet size decreased, which meant that a lower dose could be used for the nanoemulsions. Myristica fragrans oil encapsulated within chitosan nano-particles exhibited strong antimicrobial activity against A. flavus in stored rice (Das et al., 2020c). An $\alpha-$ terpineol-loaded chitosan nanoemulsion was reported to inhibit yeasts and molds growth, as well as aflatoxin $\mathrm{B}_{1}$ production in stored maize (Chaudhari et al., 2020a). Similarly, eugenol and Origanum majorana L. oils loaded into nanoemulsions have been shown to exhibit antifungal and anti-aflatoxigenic activity, thereby improving the shelf-life of stored foods (Chaudhari et al., 2020b; Das et al., 2021a). In addition, methylcellulosebased films loaded with essential oil (oregano + thyme oil) nanoemulsions have been shown to exhibit antifungal activity in rice (Hossain et al., 2019). In particular, they exhibited strong activity against A. niger, Aspergillus flavus, Aspergillus parasiticus, and Penicillium chrysogenum.

\section{SAFETY ASPECTS OF PLANT ANTIMICROBIAL BASED NANO-FORMULATIONS}

As stated earlier, plant-based antimicrobials have been widely used as therapeutics, food preservatives, and biocides for many years. In the past two decades, many studies have focused on the efficacy, biological activity, and pharmacological potential of these antimicrobials (Juneja et al., 2012; Mickymaray, 2019). However, there is still a lack of detailed information about the potential toxicity of plant-based antimicrobial nanoemulsions (Chaudhry et al., 2017). Even so, some studies on the toxicological effects of specific formulations have been reported 
(Carocho et al., 2015; Davidson et al., 2015; Jeevanandam et al., 2017). Some of the surfactants, excipients, and other additives used to formulate these nanoenabled antimicrobial systems may have toxic effects when used at sufficiently high concentrations (McClements, 2011; Simões et al., 2018). Furthermore, the small size of the droplets in nanoemulsions may alter their behavior within the human gut, which could alter their toxicity (McClements and Xiao, 2012; Ribeiro et al., 2017; Wani et al., 2018). For instance, they may be absorbed in different regions of the gastrointestinal tract, they may have different pharmacokinetic profiles, or they may interfere with the gut microbiome. There is clearly a need for a more comprehensive assessment of the potential toxicological effects of plant-based antimicrobial nanoemulsions, which would involve developing standardized methods for their proper physicochemical characterization, risk assessment, and exposure assessment (Hardy et al., 2018; Rasmussen et al., 2018). Government agencies like EFSA (European Food Safety Authorities) are developing principles for the safety evaluation and authorization of nano-based materials (Amenta et al., 2015), with the ultimate goal of facilitating the development of effective products that are also safe for use.

\section{CONCLUDING REMARKS AND FUTURE OPPORTUNITIES}

The use of synthetic compounds in food preservation and food safety applications has raised consumer concerns due to perceived adverse health effects, the development of antimicrobial resistance, and environmental pollution. To address these issues, the use of plant-based antimicrobial substances for food preservation has become an important area of research. Many of these substances cannot be used in their pure form because of solubility, stability, and activity issues. For this reason, nanoemulsion-based delivery systems

\section{REFERENCES}

Abd El Kader, A. E., and Abu Hashish, H. M. (2020). Encapsulation techniques of food bioproduct. Egypt. J. Chem. 63, 1881-1909. doi: 10.21608/ejchem.2019.16269.1993

Abdou, E. S., Galhoum, G. F., and Mohamed, E. N. (2018). Curcumin loaded nanoemulsions/pectin coatings for refrigerated chicken fillets. Food Hydrocoll. 83, 445-453. doi: 10.1016/j.foodhyd.2018.05.026

Aberkane, L., Roudaut, G., and Saurel, R. (2014). Encapsulation and oxidative stability of PUFA-rich oil microencapsulated by spray drying using pea protein and pectin. Food Bioprocess Technol. 7, 1505-1517. doi: 10.1007/s11947-013-1202-9

Acevedo-Fani, A., Soliva-Fortuny, R., and Martín-Belloso, O. (2017a). Nanoemulsions as edible coatings. Curr. Opin. Food Sci. 15, 43-49. doi: 10.1016/j.cofs.2017.06.002

Acevedo-Fani, A., Soliva-Fortuny, R., and Martín-Belloso, O. (2017b). Nanostructured emulsions and nanolaminates for delivery of active ingredients: improving food safety and functionality. Trends Food Sci. Technol. 60, 12-22. doi: 10.1016/j.tifs.2016.10.027

Akhavan, S., Assadpour, E., Katouzian, I., and Jafari, S. M. (2018). Lipid nano scale cargos for the protection and delivery of food bioactive are being designed to overcome these limitations, as well as to create targeted or controlled release systems. Nevertheless, these nanoemulsions must be carefully designed to ensure they have the required functional attributes, which involves tight control of their formulation and manufacture. In particular, the composition, concentration, size, and surface charge of the oil droplets must be designed for the specific application. One or more antimicrobial substances can be located within different locations within nanoemulsions: non-polar antimicrobials in the oil droplets; polar antimicrobials in the water phase; and, amphiphilic antimicrobials in the interfacial region.

Much of the research carried out so far has been on simple model systems. However, food matrix effects are known to have a major impact on the efficacy of antimicrobial nanoemulsions because of partitioning and interaction effects. Consequently, more studies should be carried out on the impact of plantbased antimicrobial nanoemulsions on the quality attributes, safety, and shelf-lives of real food products. In addition, more research is required to identify the mechanisms of action of different antimicrobials under different conditions, as well as their potential for causing toxicity.

\section{AUTHOR CONTRIBUTIONS}

DM planned and edited the final draft of manuscript. AD, PD, $\mathrm{PN}$, and $\mathrm{NC}$ researched the literature and wrote first draft of manuscript. All authors contributed to the article and approved the submitted version.

\section{FUNDING}

This material was partly based upon work supported by the National Institute of Food and Agriculture, USDA, Massachusetts Agricultural Experiment Station (Project Number 831) and USDA, AFRI Grants (2016-08782 and 2020-03921). ingredients and nutraceuticals. Trends Food Sci. Technol. 74, 132-146. doi: 10.1016/j.tifs.2018.02.001

Akiyama, H., Fujii, K., Yamasaki, O., Oono, T., and Iwatsuki, K. (2001). Antibacterial action of several tannins against Staphylococcus aureus. J. Antimicrob. Chemother. 48, 487-491. doi: 10.1093/jac/48.4.487

Amenta, V., Aschberger, K., Arena, M., Bouwmeester, H., Botelho Moniz, F., Brandhoff, P., et al. (2015). Regulatory aspects of nanotechnology in the agri/feed/food sector in EU and non-EU countries. Regul. Toxicol. Pharmacol. 73, 463-476. doi: 10.1016/j.yrtph.2015.06.016

Anton, N., Benoit, J. P., and Saulnier, P. (2008). Design and production of nanoparticles formulated from nano-emulsion templates-a review. J. Control. Release 128, 185-199. doi: 10.1016/j.jconrel.2008.02.007

Arancibia, C., Bayarri, S., and Costell, E. (2013). Comparing carboxymethyl cellulose and starch as thickeners in oil/water emulsions. implications on rheological and structural properties. Food Biophys. 8, 122-136. doi: 10.1007/s11483-013-9287-2

Arshad, M. S., and Batool, S. A. (2017). "Natural antimicrobials, their sources and food safety," in Food Additives, eds D. N. Karunaratne and G. Pamunuwa (London: IntechOpen Limited), 87-100. doi: 10.5772/intechopen.70197

Artiga-Artigas, M., Acevedo-Fani, A., and Martín-Belloso, O. (2017). Improving the shelf life of low-fat cut cheese using nanoemulsion-based edible coatings 
containing oregano essential oil and mandarin fiber. Food Control 76, 1-12. doi: 10.1016/j.foodcont.2017.01.001

Aruguete, D. M., Kim, B., Hochella, M. F., Ma, Y., Cheng, Y., Hoegh, A., et al. (2013). Antimicrobial nanotechnology: its potential for the effective management of microbial drug resistance and implications for research needs in microbial nanotoxicology. Environ. Sci. Process. Impacts 15, 93-102. doi: $10.1039 / \mathrm{c} 2 \mathrm{em} 30692 \mathrm{a}$

Aumeeruddy-Elalfi, Z., Gurib-Fakim, A., and Mahomoodally, F. (2015). Antimicrobial, antibiotic potentiating activity and phytochemical profile of essential oils from exotic and endemic medicinal plants of Mauritius. Ind. Crops Prod. 71, 197-204. doi: 10.1016/j.indcrop.2015.03.058

Bai, L., and McClements, D. J. (2016). Development of microfluidization methods for efficient production of concentrated nanoemulsions: comparison of singleand dual-channel microfluidizers. J. Colloid Interface Sci. 466, 206-212. doi: 10.1016/j.jcis.2015.12.039

Bajer, T., Šilha, D., Ventura, K., and Bajerová, P. (2017). Composition and antimicrobial activity of the essential oil, distilled aromatic water and herbal infusion from Epilobium parviflorum Schreb. Ind. Crops Prod. 100, 95-105. doi: 10.1016/j.indcrop.2017.02.016

Baker, J. R., Hamouda, T., Shih, A., and Andrzej, M. (2003). Non-Toxic Antimicrobial Compositions and Methods of Use. US Patent 6,559,189.

Balta, I., Brinzan, L., Stratakos, A. C., Linton, M., Kelly, C., Pinkerton, L., et al. (2017). Geraniol and linalool loaded nanoemulsions and their antimicrobial activity. Bull. Univ. Agric. Sci. Vet. Med. Cluj-Napoca. Anim. Sci. Biotechnol. 74:157. doi: 10.15835/buasvmcn-asb:0025

Baranwal, A., Srivastava, A., Kumar, P., Bajpai, V. K., Maurya, P. K., and Chandra, P. (2018). Prospects of nanostructure materials and their composites as antimicrobial agents. Front. Microbiol. 9:422. doi: 10.3389/fmicb.2018.00422

Barba, F. J., Ahrné, L., Xanthakis, E., Landerslev, M. G., and Orlien, V. (2018). "Innovative technologies for food preservation," in Innovative technologies Technologies for food Food Preservation: Inactivation of Spoilage and Pathogenic Microorganisms, eds F. J. Barba, A. S. Sant'Ana, V. Orlien and M. Koubaa (Cambridge: Academic Press), 25-51. doi: 10.1016/B978-0-12-811031-7.00002-9

Barbosa Pelegrini, P., Del Sarto, R. P., Silva, O. N., Franco, O. L., and Grossi-DeSa, M. F. (2011). Antibacterial peptides from plants: what they are and how they probably work. Biochem. Res. Int. 349. doi: 10.1155/2011/250349

Barros-Velazquez, J. (2016). Antimicrobial Food Packaging. 1st ed. San Diego, CA; New York, NY: Academic Press.

Basile, A., Sorbo, S., Spadaro, V., Bruno, M., Maggio, A., Faraone, N., et al. (2009). Antimicrobial and antioxidant activities of coumarins from the roots of Ferulago campestris (Apiaceae). Molecules 14, 939-952. doi: 10.3390/molecules14030939

Bassole, I. H. N., Ouattara, A. S., Nebie, R., Ouattara, C. A. T., Kabore, Z. I., and Traore, S. A. (2003). Chemical composition and antibacterial activities of the essential oils of Lippia chevalieri and Lippia multiflora from Burkina Faso. Phytochemistry 62, 209-212. doi: 10.1016/S0031-9422(02)00477-6

Bayarri, S., González-Tomás, L., and Costell, E. (2009). Viscoelastic properties of aqueous and milk systems with carboxymethyl cellulose. Food Hydrocoll. 23, 441-450. doi: 10.1016/j.foodhyd.2008.02.002

Belhaoues, S., Amri, S., and Bensouilah, M. (2020). Major phenolic compounds, antioxidant and antibacterial activities of Anthemis praecox Link aerial parts. South African J. Bot. 131, 200-205. doi: 10.1016/j.sajb.2020. 02.018

Bhadekar, R., and Bhola, J. (2019). "Nonconventional preservation techniques: current trends and future prospects," in Preservatives and Preservation Approaches in Beverages: Volume 15: The Science of Beverages, eds A. M. Grumezescu and A. M. Holban (Cambridge: Academic Press), 115-147. doi: 10.1016/B978-0-12-816685-7.00004-5

Bhargava, K., Conti, D. S., da Rocha, S. R. P., and Zhang, Y. (2015). Application of an oregano oil nanoemulsion to the control of foodborne bacteria on fresh lettuce. Food Microbiol. 47, 69-73. doi: 10.1016/j.fm.2014. 11.007

Boor, K. J., Wiedmann, M., Murphy, S., and Alcaine, S. (2017). A 100-year review: microbiology and safety of milk handling. J. Dairy Sci. 100, 9933-9951. doi: $10.3168 /$ jds.2017-12969

Borges, A., Ferreira, C., Saavedra, M. J., and Simões, M. (2013). Antibacterial activity and mode of action of ferulic and gallic acids against pathogenic bacteria. Microb. Drug Resist. 19, 256-265. doi: 10.1089/mdr.2012. 0244

Borrin, T. R., Georges, E. L., Moraes, I. C. F., and Pinho, S. C. (2016). Curcuminloaded nanoemulsions produced by the emulsion inversion point (EIP) method: an evaluation of process parameters and physico-chemical stability. J. Food Eng. 169, 1-9. doi: 10.1016/j.jfoodeng.2015.08.012

Bouarab Chibane, L., Degraeve, P., Ferhout, H., Bouajila, J., and Oulahal, N. (2019). Plant antimicrobial polyphenols as potential natural food preservatives. J. Sci. Food Agric. 99, 1457-1474. doi: 10.1002/jsfa.9357

Bouchemal, K., Briançon, S., Perrier, E., and Fessi, H. (2004). Nano-emulsion formulation using spontaneous emulsification: solvent, oil and surfactant optimisation. Int. J. Pharm. 280, 241-251. doi: 10.1016/j.ijpharm.2004.05.016

Buranasuksombat, U., Kwon, Y. J., Turner, M., and Bhandari, B. (2011). Influence of emulsion droplet size on antimicrobial properties. Food Sci. Biotechnol. 20, 793-800. doi: 10.1007/s10068-011-0110-x

Burt, S. (2004). Essential oils: their antibacterial properties and potential applications in foods - a review. Int. J. Food Microbiol. 94, 223-253. doi: 10.1016/j.ijfoodmicro.2004.03.022

Çakmak, H., Özselek, Y., Turan, O. Y., Firatligil, E., and Karbancioglu-Güler, F. (2020). Whey protein isolate edible films incorporated with essential oils: antimicrobial activity and barrier properties. Polym. Degrad. Stab. 179:285. doi: 10.1016/j.polymdegradstab.2020.109285

Can Karaca, A., Low, N. H., and Nickerson, M. T. (2015). Potential use of plant proteins in the microencapsulation of lipophilic materials in foods. Trends Food Sci. Technol. 42, 5-12. doi: 10.1016/j.tifs.2014.11.002

Carocho, M., Morales, P., and Ferreira, I. C. F. R. (2015). Natural food additives: quo vadis? Trends Food Sci. Technol. 45, 284-295. doi: 10.1016/j.tifs.2015.06.007

Chakraborty, A., and Dhar, P. (2017). A review on potential of proteins as an excipient for developing a nano-carrier delivery system. Crit. Rev. Ther. Drug Carrier Syst. 34, 453-488. doi: 10.1615/CritRevTherDrugCarrierSyst.2017018612

Chanamai, R., and McClements, D. J. (2000). Impact of weighting agents and sucrose on gravitational separation of beverage emulsions. J. Agric. Food Chem. 48, 5561-5565. doi: 10.1021/jf0002903

Chang, Y., McLandsborough, L., and McClements, D. J. (2012). Physical properties and antimicrobial efficacy of thyme oil nanoemulsions: influence of ripening inhibitors. J. Agric. Food Chem. 60, 12056-12063. doi: 10.1021/jf304045a

Chang, Y., McLandsborough, L., and McClements, D. J. (2013). Physicochemical properties and antimicrobial efficacy of carvacrol nanoemulsions formed by spontaneous emulsification. J. Agric. Food Chem. 61, 8906-8913. doi: $10.1021 /$ jf402147p

Chaudhari, A. K., Singh, A., Singh, V. K., Dwivedy, A. K., Das, S., Grace Ramsdam, M., et al. (2020a). Assessment of chitosan biopolymer encapsulated $\alpha$-Terpineol against fungal, aflatoxin $\mathrm{B} 1$ (AFB1) and free radicals mediated deterioration of stored maize and possible mode of action. Food Chem. 311:126010. doi: 10.1016/j.foodchem.2019.126010

Chaudhari, A. K., Singh, V. K., Das, S., Deepika, Prasad, J., Dwivedy, A. K., and Dubey, N. K. (2020b). Improvement of in vitro and in situ antifungal, AFB1 inhibitory and antioxidant activity of Origanum majorana L. essential oil through nanoemulsion and recommending as novel food preservative. Food Chem. Toxicol. 143:111536. doi: 10.1016/j.fct.2020.111536

Chaudhry, Q., Watkins, R., and Castle, L. (2017). Nanotechnologies in Food: what, why \& how? RSC Nanosci. Nanotechnol. 1-19. doi: 10.1039/9781782626879-00001

Chouhan, S., Sharma, K., and Guleria, S. (2017). Antimicrobial activity of some essential oils-present status and future perspectives. Medicines 4:58. doi: 10.3390/medicines4030058

Choupanian, M., Omar, D., Basri, M., and Asib, N. (2017). Preparation and characterization of neem oil nanoemulsion formulations against Sitophilus oryzae and Tribolium castaneum adults. J. Pestic. Sci. 42, 158-165. doi: 10.1584/jpestics.D17-032

Chu, Y., Gao, C. C., Liu, X., Zhang, N., Xu, T., Feng, X., et al. (2020). Improvement of storage quality of strawberries by pullulan coatings incorporated with cinnamon essential oil nanoemulsion. LWT-Food Sci. Technol. 122:109054. doi: 10.1016/j.lwt.2020.109054

Constantinescu, A. M., Tita, M. A., and Georgescu, C. (2019). Comparative analysis of yoghurts obtained with bioactive compounds. Bull. Transilv. 
Univ. Brasov, Ser. II For. Wood Ind. Agric. Food Eng. 12, 73-84. doi: 10.31926/but.fwiafe.2019.12.61.2.6

Coppo, E., and Marchese, A. (2014). Antibacterial activity of polyphenols. Curr. Pharm. Biotechnol. 15, 380-390. doi: 10.2174/138920101504140825121142

Cowan, M. M. (1999). Plant products as antimicrobial agents. Clin. Microbiol. Rev. 12, 564-582.

Cushnie, T. P. T., Cushnie, B., and Lamb, A. J. (2014). Alkaloids: an overview of their antibacterial, antibiotic-enhancing and antivirulence activities. Int. J. Antimicrob. Agents 44, 377-386. doi: 10.1016/j.ijantimicag.2014.06.001

Dabbaghi, A., Kabiri, K., Ramazani, A., Zohuriaan-Mehr, M. J., and Jahandideh, A. (2019). Synthesis of bio-based internal and external cross-linkers based on tannic acid for preparation of antibacterial superabsorbents. Polym. Adv. Technol. 30, 2894-2905. doi: 10.1002/pat.4722

Dai, J., and Mumper, R. J. (2010). Plant phenolics: extraction, analysis and their antioxidant and anticancer properties. Molecules 15, 7313-7352. doi: 10.3390/molecules15107313

Das, A. K., Nanda, P. K., Bandyopadhyay, S., Banerjee, R., Biswas, S., and McClements, D. J. (2020a). Application of nanoemulsion-based approaches for improving the quality and safety of muscle foods: a comprehensive review. Compr. Rev. Food Sci. Food Saf. 19, 2677-2700. doi: 10.1111/1541-4337.12604

Das, A. K., Nanda, P. K., Chowdhury, N. R., Dandapat, P., Gagaoua, M., Chauhan, P., et al. (2021b). Application of pomegranate by-products in muscle foods: oxidative indices, colour stability, shelf life and health benefits. Molecules 26:467. doi: 10.3390/molecules26020467

Das, A. K., Nanda, P. K., Das, A., and Biswas, S. (2019). "Hazards and safety issues of meat and meat products," in Food Safety and Human Health, eds R. L. Singh, and S. Mondal (Cambridge: Elsevier Academic Press), 145-168. doi: 10.1016/b978-0-12-816333-7.00006-0

Das, A. K., Nanda, P. K., Madane, P., Biswas, S., Das, A., Zhang, W., et al. (2020b). A comprehensive review on antioxidant dietary fibre enriched meat-based functional foods. Trends Food Sci. Technol. 99, 323-336. doi: 10.1016/j.tifs.2020.03.010

Das, S., Singh, V. K., Dwivedy, A. K., Chaudhari, A. K., Deepika, and Dubey, N. K. (2021a). Eugenol loaded chitosan nanoemulsion for food protection and inhibition of Aflatoxin B1 synthesizing genes based on molecular docking. Carbohyd. Polym. 255:117339. doi: 10.1016/j.carbpol.2020.117339

Das, S., Singh, V. K., Dwivedy, A. K., Chaudhari, A. K., Upadhyay, N., Singh, A., et al. (2020c). Fabrication, characterization and practical efficacy of Myristica fragrans essential oil nanoemulsion delivery system against postharvest biodeterioration. Ecotoxicol. Environ. Safety 189:110000. doi: 10.1016/j.ecoenv.2019.110000

Davidson, P. M., Cekmer, H. B., Monu, E. A., and Techathuvanan, C. (2015). “The use of natural antimicrobials in food: an overview," in Handbook of Natural Antimicrobials for Food Safety and Quality, ed T. M. Taylor (Cambridge: Woodhead Publishing), 1-27. doi: 10.1016/B978-1-78242-034-7.00001-3

Davidson, P. M., Taylor, T. M., and Schmidt, S. E. (2014). "Chemical preservatives and natural antimicrobial compounds," in Food Microbiology: Fundamentals, and Frontiers, 3rd Edn, eds M. P. Doyle, F. Diez-Gonzalez, and C. Hill (Hoboken: Wiley Publishing), 713-745. doi: 10.1128/9781555815912.ch33

Dávila-Rodríguez, M., López-Malo, A., Palou, E., Ramírez-Corona, N., and Jiménez-Munguía, M. T. (2019). Antimicrobial activity of nanoemulsions of cinnamon, rosemary, and oregano essential oils on fresh celery. LWT 112, 14.108247.doi: 10.1016/j.lwt.2019.06.014

Decarlo, A., Zeng, T., Dosoky, N. S., Satyal, P., and Setzer, W. N. (2020). The essential oil composition and antimicrobial activity of Liquidambar formosana oleoresin. Plants 9, 1-15. doi: 10.3390/plants9070822

Dey, T. K., Banerjee, P., Chatterjee, R., and Dhar, P. (2018). Designing of $\omega-3$ PUFA enriched biocompatible nanoemulsion with sesame protein isolate as a natural surfactant: focus on enhanced shelf-life stability and biocompatibility. Colloids Surfaces A Physicochem. Eng. Asp. 538, 36-44. doi: 10.1016/j.colsurfa.2017.10.066

Di Pasqua, R., Hoskins, N., Betts, G., and Mauriello, G. (2006). Changes in membrane fatty acids composition of microbial cells induced by addiction of thymol, carvacrol, limonene, cinnamaldehyde, and eugenol in the growing media. J. Agric. Food Chem. 54, 2745-2749. doi: 10.1021/jf0527221

Diao, W. R., Hu, Q. P., Zhang, H., and Xu, J. G. (2014). Chemical composition, antibacterial activity and mechanism of action of essential oil from seeds of fennel (Foeniculum vulgare Mill.). Food Control 35, 109-116. doi: 10.1016/j.foodcont.2013.06.056

Dietrich, H., and Pour Nikfardjam, M. S. (2017). "Influence of phenolic compounds and tannins on wine-related microorganisms," in Biology of Microorganisms on Grapes, in Must and in Wine, eds H. König, G. Unden, and J. Fröhlich (Berlin: Springer-Verlag Berlin Heidelberg), 421-454. doi: 10.1007/978-3-319-60021-5_18

Donsì, F., Annunziata, M., Vincensi, M., and Ferrari, G. (2012). Design of nanoemulsion-based delivery systems of natural antimicrobials: effect of the emulsifier. J. Biotechnol. 159, 342-350. doi: 10.1016/j.jbiotec.2011. 07.001

Donsì, F., and Ferrari, G. (2016). Essential oil nanoemulsions as antimicrobial agents in food. J. Biotechnol. 233, 106-120. doi: 10.1016/j.jbiotec.2016. 07.005

Donsì, F., Senatore, B., Huang, Q., and Ferrari, G. (2010). Development of novel pea protein-based nanoemulsions for delivery of nutraceuticals. J. Agric. Food Chem. 58, 10653-10660. doi: 10.1021/jf101804g

Evans, W. C. (2009). “Alkaloids," in Trease and Evans Pharmacognosy, eds P. Graham, J. Urguhart, and F. Conn (Edingburgh: Elsevier), 354-356.

Falcone Ferreyra, M. L., Rius, S. P., and Casati, P. (2012). Flavonoids: biosynthesis, biological functions, and biotechnological applications. Front. Plant Sci. 3:222. doi: 10.3389/fpls.2012.00222

Falleh, H., Ben Jemaa, M., Saada, M., and Ksouri, R. (2020). Essential oils: a promising eco-friendly food preservative. Food Chem. 330:127268. doi: 10.1016/j.foodchem.2020.127268

Fan, X., Ngo, H., and Wu, C. (2018). "Natural and bio-based antimicrobials: a review," in ACS Symposium Series (Washington), 1-24. doi: 10.1021/bk-2018-1287.ch001

Fathima, A., and Rao, J. R. (2016). Selective toxicity of catechin-a natural flavonoid towards bacteria. Appl. Microbiol. Biotechnol. 100, 6395-6402. doi: 10.1007/s00253-016-7492-x

Feng, J., Zhang, Q., Liu, Q., Zhu, Z., McClements, D. J., and Jafari, S. M. (2018). "Application of nanoemulsions in formulation of pesticides," in Nanoemulsions: Formulation, Applications, and Characterization, eds S. M. Jafari and D. J. McClements (Cambridge: Academic Press), 379-413. doi: 10.1016/B978-0-12-811838-2.00012-6

Fernandes, C. P., de Almeida, F. B., Silveira, A. N., Gonzalez, M. S., Mello, C. B., Feder, D., et al. (2014). Development of an insecticidal nanoemulsion with Manilkara subsericea (Sapotaceae) extract. J. Nanobiotechnology 12:22. doi: 10.1186/1477-3155-12-22

Ferreira, C. D., and Nunes, I. L. (2019). Oil nanoencapsulation: development, application, and incorporation into the food market. Nanoscale Res. Lett. 14:9. doi: 10.1186/s11671-018-2829-2

Ferreira, J. P., Alves, D., Neves, O., Silva, J., Gibbs, P. A., and Teixeira, P. C. (2010) Effects of the components of two antimicrobial emulsions on food-borne pathogens. Food Control 21, 227-230. doi: 10.1016/j.foodcont.2009.05.018

Franco, O. L. (2011). Peptide promiscuity: an evolutionary concept for plant defense. FEBS Lett. 585, 995-1000. doi: 10.1016/j.febslet.2011.03.008

Ghaderi-Ghahfarokhi, M., Barzegar, M., Sahari, M. A., Ahmadi Gavlighi, H., and Gardini, F. (2017). Chitosan-cinnamon essential oil nanoformulation: application as a novel additive for controlled release and shelf life extension of beef patties. Int. J. Biol. Macromol. 102, 19-28. doi: 10.1016/j.ijbiomac.2017.04.002

Gharsallaoui, A., Roudaut, G., Chambin, O., Voilley, A., and Saurel, R. (2007). Applications of spray-drying in microencapsulation of food ingredients: an overview. Food Res. Int. 40, 1107-1121. doi: 10.1016/j.foodres.2007.07.004

Ghosh, V., Mukherjee, A., and Chandrasekaran, N. (2014). Eugenolloaded antimicrobial nanoemulsion preserves fruit juice against microbial spoilage. Colloids Surfaces B Biointerfaces 114, 392-397. doi: 10.1016/j.colsurfb.2013.10.034

Goel, S., Parihar, P. S., and Meshram, V. (2020). "Plant-derived quinones as a source of antibacterial and anticancer agents," in Bioactive Natural Products in Drug Discovery, eds J. Singh, V. Meshram, and M. Gupta (Singapore: Springer Singapore), 245-279. doi: 10.1007/978-981-15-1394-7_6

Górniak, I., Bartoszewski, R., and Króliczewski, J. (2019). Comprehensive review of antimicrobial activities of plant flavonoids. Phytochem. Rev. 18, 241-272. doi: 10.1007/s11101-018-9591-z 
Guerra-Rosas, M. I., Morales-Castro, J., Ochoa-Martínez, L. A., Salvia-Trujillo, L., and Martín-Belloso, O. (2016). Long-term stability of food-grade nanoemulsions from high methoxyl pectin containing essential oils. Food Hydrocoll. 52, 438-446. doi: 10.1016/j.foodhyd.2015.07.017

Gumus, C. E., Decker, E. A., and McClements, D. J. (2017). Formation and stability of $\omega-3$ oil emulsion-based delivery systems using plant proteins as emulsifiers: lentil, pea, and faba bean proteins. Food Biophys. 12, 186-197. doi: 10.1007/s11483-017-9475-6

Gupta, N., Rai, D. B., Jangid, A. K., and Kulhari, H. (2019). "Use of nanotechnology in antimicrobial therapy," in Methods in Microbiology, eds V. Gurtler, A. S. Ball, and S. Soni (Elsevier), 143-172. doi: 10.1016/bs.mim.2019.04.004

Gutierrez, J., Barry-Ryan, C., and Bourke, P. (2008). The antimicrobial efficacy of plant essential oil combinations and interactions with food ingredients. Int. J. Food Microbiol. 124, 91-97. doi: 10.1016/j.ijfoodmicro.2008.02.028

Hamilton-Miller, J. M. T. (1995). Antimicrobial properties of tea (Camellia sinensis L.). Antimicrob. Agents Chemother. 39, 2375-2377. doi: 10.1128/AAC.39.11.2375

Hardy, A., Benford, D., Halldorsson, T., Jeger, M. J., Knutsen, H. K., More, S., et al. (2018). Guidance on risk assessment of the application of nanoscience and nanotechnologies in the food and feed chain: part 1, human and animal health. EFSA J. 16:27. doi: 10.2903/j.efsa.2018.5327

Heydari, M., Amirjani, A., Bagheri, M., Sharifian, I., and Sabahi, Q. (2020). Eco-friendly pesticide based on peppermint oil nanoemulsion: preparation, physicochemical properties, and its aphicidal activity against cotton aphid. Environ. Sci. Pollut. Res. 27, 6667-6679. doi: 10.1007/s11356-019-07332-y

Hossain, F., Follett, P., Vu, K. D., Salmieri, S., Fraschini, C., Jamshidian, M., et al. (2019). Antifungal activity of combined treatments of active methylcellulosebased films containing encapsulated nanoemulsion of essential oils and $\gamma$-irradiation: in vitro and in situ evaluations. Cellulose 26, 1335-1354. doi: 10.1007/s10570-018-2135-2

Hu, M., Xie, F., Zhang, S., Li, Y., and Qi, B. (2020). Homogenization pressure and soybean protein concentration impact the stability of perilla oil nanoemulsions. Food Hydrocoll. 101:105575. doi: 10.1016/j.foodhyd.2019.105575

Hussain, A. I., Anwar, F., Hussain Sherazi, S. T., and Przybylski, R. (2008). Chemical composition, antioxidant and antimicrobial activities of basil (Ocimum basilicum) essential oils depends on seasonal variations. Food Chem. 108, 986-995. doi: 10.1016/j.foodchem.2007.12.010

Hygreeva, D., and Pandey, M. C. (2016). Novel approaches in improving the quality and safety aspects of processed meat products through high pressure processing technology - a review. Trends Food Sci. Technol. 54, 175-185. doi: $10.1016 /$ j.tifs.2016.06.002

Hyldgaard, M., Mygind, T., and Meyer, R. L. (2012). Essential oils in food preservation: mode of action, synergies, and interactions with food matrix components. Front. Microbiol. 3:12. doi: 10.3389/fmicb.2012.00012

Ibrahim, S. S. (2020). "Essential oil nanoformulations as a novel method for insect pest control in horticulture," in Horticultural Crops, eds H. K. Baimey, N. Hamamouch, and Y. A. Kolombia (London: IntechOpen Limited), 1-14. doi: 10.5772/intechopen.80747

Jafari, S. M., Assadpoor, E., He, Y., and Bhandari, B. (2008). Re-coalescence of emulsion droplets during high-energy emulsification. Food Hydrocoll. 22, 1191-1202. doi: 10.1016/j.foodhyd.2007.09.006

Jeevanandam, J., Aing, Y. S., Chan, Y. S., Pan, S., and Danquah, M. K. (2017). "Nanoformulation and application of phytochemicals as antimicrobial agents," in Antimicrobial Nanoarchitectonics: From Synthesis to Applications, ed A. M. Grumezescu (Elsevier), 61-82. doi: 10.1016/B978-0-323-52733-0.00003-3

Jiang, T., Liao, W., and Charcosset, C. (2020). Recent advances in encapsulation of curcumin in nanoemulsions: a review of encapsulation technologies, bioaccessibility and applications. Food Res. Int. 132:109035. doi: 10.1016/j.foodres.2020.109035

Jiménez, M., Domínguez, J. A., Pascual-Pineda, L. A., Azuara, E., and Beristain, C. I. (2018). Elaboration and characterization of O/W cinnamon (Cinnamomum zeylanicum) and black pepper (Piper nigrum) emulsions. Food Hydrocoll. 77, 902-910. doi: 10.1016/j.foodhyd.2017.11.037

Joe, M. M., Benson, A., Saravanan, V. S., and Sa, T. (2015). In vitro antibacterial activity of nanoemulsion formulation on biofilm, AHL production, hydrolytic enzyme activity, and pathogenicity of Pectobacterium carotovorum sub sp. carotovorum. Physiol. Mol. Plant Pathol. 91, 46-55. doi: 10.1016/j.pmpp.2015.05.009
Joe, M. M., Chauhan, P. S., Bradeeba, K., Shagol, C., Sivakumaar, P. K., and Sa, T. (2012). Influence of sunflower oil based nanoemulsion (AUSN-4) on the shelf life and quality of Indo-Pacific king mackerel (Scomberomorus guttatus) steaks stored at $20^{\circ}$ C. Food Control 23, 564-570. doi: 10.1016/j.foodcont.2011.08.032

Jones, M. N., Song, Y. H., Kaszuba, M., and Reboiras, M. D. (1997). The interaction of phospholipid liposomes with bacteria and their use in the delivery of bactericides. J. Drug Target. 5, 25-34. doi: 10.3109/10611869708995855

Juliani, H. R., Biurrun, F., Koroch, A. R., Oliva, M. M., Demo, M. S., Trippi, V. S., et al. (2002). Chemical constituents and antimicrobial activity of the essential oil of Lantana xenica. Planta Med. 68, 762-764. doi: 10.1055/s-20 02-33803

Juneja, V. K., Dwivedi, H. P., and Yan, X. (2012). Novel natural food antimicrobials. Annu. Rev. Food Sci. Technol. 3, 381-403. doi: 10.1146/annurev-food-022811-101241

Kaczmarek, B. (2020). Tannic acid with antiviral and antibacterial activity as a promising component of biomaterials-a minireview. Materials 13:224. doi: $10.3390 / \mathrm{ma1} 3143224$

Kaur, R., and Kaur, L. (2020). Encapsulated natural antimicrobials: a promising way to reduce microbial growth in different food systems. Food Control. doi: 10.1016/j.foodcont.2020.107678

Kennedy, R. O., and Thornes, R. D. (1997). Coumarins: Biology, Applications and Mode of Action. Hoboken, NJ: Willey.

Keykhosravy, K., Khanzadi, S., Hashemi, M., and Azizzadeh, M. (2020). Chitosanloaded nanoemulsion containing Zataria multiflora Boiss and Bunium persicum Boiss essential oils as edible coatings: its impact on microbial quality of Turkey meat and fate of inoculated pathogens. Int. J. Biol. Macromol. 150, 904-913. doi: 10.1016/j.ijbiomac.2020.02.092

Khan, M. R., Sadiq, M. B., and Mehmood, Z. (2020). Development of edible gelatin composite films enriched with polyphenol loaded nanoemulsions as chicken meat packaging material. CYTA J. Food 18, 137-146. doi: 10.1080/19476337.2020.1720826

Khanzadi, S., Azizian, A., Hashemi, M., and Azizzadeh, M. (2019). Chemical composition and antibacterial activity of the emulsion and nano-emulsion of Ziziphora clinopodioides essential oil against Escherichia coli O157:H7. J. Hum. Environ. Heal. Promot. 5, 94-97. doi: 10.29252/jhehp.5.2.8

Khanzadi, S., Keykhosravy, K., Hashemi, M., and Azizzadeh, M. (2020). Alginate coarse/nanoemulsions containing Zataria multiflora Boiss essential oil as edible coatings and the impact on microbial quality of trout fillet. Aquac. Res. 51, 873-881. doi: 10.1111/are.14418

Kordali, S., Kotan, R., Mavi, A., Cakir, A., Ala, A., and Yildirim, A. (2005). Determination of the chemical composition and antioxidant activity of the essential oil of Artemisia dracunculus and of the antifungal and antibacterial activities of Turkish Artemisia absinthium, A. dracunculus, Artemisia santonicum, and Artemisia spicig. J. Agric. Food Chem. 53, 9452-9458. doi: 10.1021/jf0516538

Krishnamoorthy, R., Athinarayanan, J., Periasamy, V. S., Adisa, A. R., AlShuniaber, M. A., Gassem, M. A., et al. (2018). Antimicrobial activity of nanoemulsion on drug-resistant bacterial pathogens. Microb. Pathog. 120, 85-96. doi: 10.1016/j.micpath.2018.04.035

Li, S., Sun, J., Yan, J., Zhang, S., Shi, C., McClements, D. J., et al. (2021) Development of antibacterial nanoemulsions incorporating thyme oil: layer-by-layer self-assembly of whey protein isolate and chitosan hydrochloride. Food Chem. 339:128016. doi: 10.1016/j.foodchem.2020. 128016

Liang, R., Xu, S., Shoemaker, C. F., Li, Y., Zhong, F., and Huang, Q. (2012). Physical and antimicrobial properties of peppermint oil nanoemulsions. J. Agric. Food Chem. 60, 7548-7555. doi: 10.1021/jf301129k

Liu, J., Du, C., Beaman, H. T., and Monroe, M. B. B. (2020). Characterization of phenolic acid antimicrobial and antioxidant structure-property relationships. Pharmaceutics 12:419. doi: 10.3390/pharmaceutics12050419

Liu, Q., Zhang, M., Bhandari, B., Xu, J., and Yang, C. (2020). Effects of nanoemulsion-based active coatings with composite mixture of star anise essential oil, polylysine, and nisin on the quality and shelf life of ready-to-eat Yao meat products. Food Control 107:106771. doi: 10.1016/j.foodcont.2019.106771

Lohith Kumar, D. H., and Sarkar, P. (2018). Encapsulation of bioactive compounds using nanoemulsions. Environ. Chem. Lett. 16, 59-70. doi: 10.1007/s10311-017-0663-x 
López-Meza, J. E., Ochoa-Zarzosa, A., Barboza-Corona, J. E., and Bideshi, D. K. (2015). Antimicrobial peptides: current and potential applications in biomedical therapies. Biomed Res. Int. 2015:367243. doi: 10.1155/2015/ 367243

Lu, W. C., Huang, D. W., Wang, C. C. R., Yeh, C. H., Tsai, J. C., Huang, Y. T., et al. (2018). Preparation, characterization, and antimicrobial activity of nanoemulsions incorporating citral essential oil. J. Food Drug Anal. 26, 82-89. doi: 10.1016/j.jfda.2016.12.018

Ma, P., Zeng, Q., Tai, K., He, X., Yao, Y., Hong, X., et al. (2017). Preparation of curcumin-loaded emulsion using high pressure homogenization: impact of oil phase and concentration on physicochemical stability. LWT 84, 34-46. doi: 10.1016/j.lwt.2017.04.074

Ma, Q., Davidson, P. M., and Zhong, Q. (2016). Nanoemulsions of thymol and eugenol co-emulsified by lauric arginate and lecithin. Food Chem. 206, 167-173. doi: 10.1016/j.foodchem.2016.03.065

Mabhiza, D., Chitemerere, T., and Mukanganyama, S. (2016). Antibacterial properties of alkaloid extracts from Callistemon citrinus and Vernonia adoensis against Staphylococcus aureus and Pseudomonas aeruginosa. Int. J. Med. Chem. 2016, 1-7. doi: 10.1155/2016/6304163

Man, A., Santacroce, L., Jacob, R., Mare, A., and Man, L. (2019). Antimicrobial activity of six essential oils against a group of human pathogens: a comparative study. Pathogens 8:15. doi: 10.3390/pathogens8010015

Marei, G. I. K., Rabea, E. I., and Badawy, M. E. I. (2018). Preparation and characterizations of chitosan/citral nanoemulsions and their antimicrobial activity. Appl. Food Biotechnol. 5, 69-78. doi: 10.22037/afb.v5i2.19005

Martins, J. T., Ramos, Ó. L., Pinheiro, A. C., Bourbon, A. I., Silva, H. D., Rivera, M. C., et al. (2015). Edible bio-based nanostructures: delivery, absorption and potential toxicity. Food Eng. Rev. 7, 491-513. doi: 10.1007/s12393-015-9116-0

Martucci, J. F., Gende, L. B., Neira, L. M., and Ruseckaite, R. A. (2015). Oregano and lavender essential oils as antioxidant and antimicrobial additives of biogenic gelatin films. Ind. Crops Prod. 71, 205-213. doi: 10.1016/j.indcrop.2015.03.079

Matsuzaki, K., Murase, O., Fujii, N., and Miyajima, K. (1995). Translocation of a channel-forming antimicrobial peptide, magainin 2, across lipid bilayers by forming a pore. Biochemistry 34, 6521-6526. doi: 10.1021/bi00019a033

McClements, D. J. (2005). "Emulsion stability," in Food Emulsions: Principles, Practice, and Techniques, ed D. J. McClements (Boca Raton, FL: CRC Press), 269-339. doi: 10.1007/BF02637935

McClements, D. J. (2011). Edible nanoemulsions: Fabrication, properties, and functional performance. Soft Matter 7, 2297-2316. doi: 10.1039/c0sm00549e

McClements, D. J. (2016). Food Emulsions: Principles, Practice, and Techniques. 3 rd Edn. Boca Raton, FL: CRC Press Taylor and Francis Group.

McClements, D. J. (2020). Nanotechnology approaches for improving the healthiness and sustainability of the modern food supply. ACS Omega, 5, 29623-29630. doi: 10.1021/acsomega.0c04050

McClements, D. J., and Rao, J. (2011). Food-grade nanoemulsions: formulation, fabrication, properties, performance, biological fate, and potential toxicity. Crit. Rev. Food Sci. Nutr. 51, 285-330. doi: 10.1080/10408398.2011.559558

McClements, D. J., and Xiao, H. (2012). Potential biological fate of ingested nanoemulsions: influence of particle characteristics. Food Funct. 3, 202-220. doi: $10.1039 / \mathrm{clfo} 10193 \mathrm{e}$

Meneguetti, B. T., Machado, L., dos, S., Oshiro, K. G. N., Nogueira, M. L., Carvalho, C. M. E., et al. (2017). Antimicrobial peptides from fruits and their potential use as biotechnological tools-a review and outlook. Front. Microbiol. 7:136. doi: $10.3389 /$ fmicb.2016.02136

Mercer, D. K., Torres, M. D. T., Duay, S. S., Lovie, E., Simpson, L., von Köckritz-Blickwede, M., et al. (2020). Antimicrobial susceptibility testing of antimicrobial peptides to better predict efficacy. Front. Cell. Infect. Microbiol. 10:326. doi: 10.3389/fcimb.2020. 00326

Mickymaray, S. (2019). Efficacy and mechanism of traditional medicinal plants and bioactive compounds against clinically important pathogens. Antibiotics 8:257. doi: 10.3390/antibiotics8040257

Milani, M. A., Dana, M. G., Ghanbarzadeh, B., Alizadeh, A., and Afshar, P. G. (2020). Effect of novel bioactive coating enriched with nanoemulsion of mustard essential oil on the quality of Turkey meat. J. Food Nutr. Res. 59, 71-80. Available online at: https://www.vup.sk/index.php?mainID=2\& navID $=36$ \&version $=2$ \&volume $=59$ \&article $=2177$
Mirhosseini, H., Tan, C. P., Aghlara, A., Hamid, N. S. A., Yusof, S., and Chern, B. H. (2008). Influence of pectin and CMC on physical stability, turbidity loss rate, cloudiness and flavor release of orange beverage emulsion during storage. Carbohydr. Polym. 73, 83-91. doi: 10.1016/j.carbpol.2007.11.002

Mishra, D. (2018). Antibacterial activity of alkaloids present in plant Achyranthes aspera. Pharma Innov. J. 7, 147-153.

Modarres-Gheisari, S. M. M., Gavagsaz-Ghoachani, R., Malaki, M., Safarpour, P., and Zandi, M. (2019). Ultrasonic nano-emulsification - a review. Ultrason. Sonochem. 52, 88-105. doi: 10.1016/j.ultsonch.2018.11.005

Moghimi, R., Ghaderi, L., Rafati, H., Aliahmadi, A., and Mcclements, D. J. (2016). Superior antibacterial activity of nanoemulsion of Thymus daenensis essential oil against E. coli. Food Chem. 194, 410-415. doi: 10.1016/j.foodchem.2015.07.139

Moraes-Lovison, M., Marostegan, L. F. P., Peres, M. S., Menezes, I. F., Ghiraldi, M., Rodrigues, R. A. F., et al. (2017). Nanoemulsions encapsulating oregano essential oil: production, stability, antibacterial activity and incorporation in chicken pâté. LWT 77, 233-240. doi: 10.1016/j.lwt.2016.11.061

Mothershaw, A. S., and Jaffer, T. (2004). Antimicrobial activity of foods with different physio-chemical characteristics. Int. J. Food Prop. 7, 629-638. doi: 10.1081/JFP-200033062

Moumni, S., Elaissi, A., Trabelsi, A., Merghni, A., Chraief, I., Jelassi, B., et al. (2020). Correlation between chemical composition and antibacterial activity of some lamiaceae species essential oils from Tunisia. BMC Complement. Med. Ther. 20:103. doi: 10.1186/s12906-020-02888-6

Mousavi Khaneghah, A., Hashemi, S. M. B., and Limbo, S. (2018). Antimicrobial agents and packaging systems in antimicrobial active food packaging: an overview of approaches and interactions. Food Bioprod. Process. 111, 1-19. doi: 10.1016/j.fbp.2018.05.001

Mulqueen, P. (2003). Recent advances in agrochemical formulation. Adv. Colloid Interface Sci. 106, 83-107. doi: 10.1016/S0001-8686(03)00106-4

Negi, P. S., Jayaprakasha, G. K., Rao, L. J. M., and Sakariah, K. K. (1999). Antibacterial activity of turmeric oil: a byproduct from curcumin manufacture. J. Agric. Food Chem. 47, 4297-4300. doi: 10.1021/jf990308d

Nielsen, C. K., Kjems, J., Mygind, T., Snabe, T., Schwarz, K., Serfert, Y., et al. (2016). Enhancing the antibacterial efficacy of isoeugenol by emulsion encapsulation. Int. J. Food Microbiol. 229, 7-14. doi: 10.1016/j.ijfoodmicro.2016.04.002

Nielsen, C. K., Kjems, J., Mygind, T., Snabe, T., Schwarz, K., Serfert, Y., et al. (2017) Antimicrobial effect of emulsion-encapsulated isoeugenol against biofilms of food pathogens and spoilage bacteria. Int. J. Food Microbiol. 242, 7-12. doi: 10.1016/j.ijfoodmicro.2016.11.002

Nirmal, N. P., Mereddy, R., Li, L., and Sultanbawa, Y. (2018). Formulation, characterisation and antibacterial activity of lemon myrtle and anise myrtle essential oil in water nanoemulsion. Food Chem. 254, 1-7. doi: 10.1016/j.foodchem.2018.01.173

Noori, S., Zeynali, F., and Almasi, H. (2018). Antimicrobial and antioxidant efficiency of nanoemulsion-based edible coating containing ginger (Zingiber officinale) essential oil and its effect on safety and quality attributes of chicken breast fillets. Food Control 84, 312-320. doi: 10.1016/j.foodcont.2017.08.015

Nussinovitch, A. (1997). Hydrocolloids Applications: Gum Technology in the Food and other Industries. New York, NY: Springer US.

Obiang-Obounou, B. W., Kang, O. H., Choi, J. G., Keum, J. H., Kim, S. B., Mun, S. H., et al. (2011). The mechanism of action of sanguinarine against methicillin-resistant Staphylococcus aureus. J. Toxicol. Sci. 36, 277-283. doi: 10.2131 /jts.36.277

Othman, L., Sleiman, A., and Abdel-Massih, R. M. (2019). Antimicrobial activity of polyphenols and alkaloids in middle eastern plants. Front. Microbiol. 10:911. doi: 10.3389/fmicb.2019.00911

Otoni, C. G., Pontes, S. F. O., Medeiros, E. A. A., and Soares, N. D. F. F. (2014). Edible films from methylcellulose and nanoemulsions of clove bud (Syzygium aromaticum) and oregano (Origanum vulgare) essential oils as shelf life extenders for sliced bread. J. Agric. Food Chem. 62, 5214-5219. doi: 10.1021/jf501055f

Ozogul, Y., Kuley Boga, E., Akyol, I., Durmus, M., Ucar, Y., Regenstein, J. M., et al. (2020). Antimicrobial activity of thyme essential oil nanoemulsions on spoilage bacteria of fish and food-borne pathogens. Food Biosci. 36:635. doi: 10.1016/j.fbio.2020.100635

Pabast, M., Shariatifar, N., Beikzadeh, S., and Jahed, G. (2018). Effects of chitosan coatings incorporating with free or nano-encapsulated Satureja plant 
essential oil on quality characteristics of lamb meat. Food Control 91, 185-192. doi: 10.1016/j.foodcont.2018.03.047

Pan, K., Luo, Y., Gan, Y., Baek, S. J., and Zhong, Q. (2014). PHdriven encapsulation of curcumin in self-assembled casein nanoparticles for enhanced dispersibility and bioactivity. Soft Matter 10, 6820-6830. doi: $10.1039 / \mathrm{c} 4 \mathrm{sm} 00239 \mathrm{c}$

Pandey, A., and Negi, P. S. (2018). Phytochemical composition, in vitro antioxidant activity and antibacterial mechanisms of Neolamarckia cadamba fruits extracts. Nat. Prod. Res. 32, 1189-1192. doi: 10.1080/14786419.2017. 1323209

Pardo, G., and Zufía, J. (2012). Life cycle assessment of food-preservation technologies. J. Clean. Prod. 28, 198-207. doi: 10.1016/j.jclepro.2011.10.016

Pathak, M. (2017). "Nanoemulsions and their stability for enhancing functional properties of food ingredients," in Nanotechnology Applications in Food: Flavor, Stability, Nutrition and Safety, eds A. E. Oprea and A. M. Grumezescu (Cambridge: Academic Press), 87-106. doi: 10.1016/B978-0-12-811942-6.00005-4

Prakash, A., Baskaran, R., Paramasivam, N., and Vadivel, V. (2018). Essential oil based nanoemulsions to improve the microbial quality of minimally processed fruits and vegetables: a review. Food Res. Int. 111, 509-523. doi: 10.1016/j.foodres.2018.05.066

Quinto, E. J., Caro, I., Villalobos-Delgado, L. H., Mateo, J., De-Mateosilleras, B., and Redondo-Del-río, M. P. (2019). Food safety through natural antimicrobials. Antibiotics 8:208. doi: 10.3390/antibiotics 8040208

Radaelli, M., da Silva, B. P., Weidlich, L., Hoehne, L., Flach, A., da Costa, L. A. M. A., et al. (2016). Antimicrobial activities of six essential oils commonly used as condiments in Brazil against Clostridium perfringens. Brazil. J. Microbiol. 47, 424-430. doi: 10.1016/j.bjm.2015.10.001

Rao, J., Chen, B., and McClements, D. J. (2019). Improving the efficacy of essential oils as antimicrobials in foods: mechanisms of action. Annu. Rev. Food Sci. Technol. 10, 365-387. doi: 10.1146/annurev-food-032818-121727

Rasmussen, K., Rauscher, H., Gottardo, S., Hoekstra, E., Schoonjans, R., Peters, R., et al. (2018). "Regulatory status of nanotechnologies in food in the EU,' in Nanomaterials for Food Applications, eds A. L. Rubio, M. J. F. Rovira, M. M. Sanz, and L. G. Gómez-Mascaraque (Elsevier), 381-410. doi: 10.1016/B978-0-12-814130-4.00013-0

Ray, S., Raychaudhuri, U., and Chakraborty, R. (2016). An overview of encapsulation of active compounds used in food products by drying technology. Food Biosci. 13, 76-83. doi: 10.1016/j.fbio.2015. 12.009

Ren, G., Sun, Z., Wang, Z., Zheng, X., Xu, Z., and Sun, D. (2019). Nanoemulsion formation by the phase inversion temperature method using polyoxypropylene surfactants. J. Colloid Interface Sci. 540, 177-184. doi: 10.1016/j.jcis.2019.01.018

Retta, D., Dellacassa, E., Villamil, J., Suárez, S. A., and Bandoni, A. L. (2012). Marcela, a promising medicinal and aromatic plant from Latin America: a review. Ind. Crops Prod. 38, 27-38. doi: 10.1016/j.indcrop.2012.01.006

Reygaert, W. C. (2014). The antimicrobial possibilities of green tea. Front. Microbiol. 5:434. doi: 10.3389/fmicb.2014.00434

Ribeiro, A. R., Leite, P. E., Falagan-Lotsch, P., Benetti, F., Micheletti, C., Budtz, H. C., et al. (2017). Challenges on the toxicological predictions of engineered nanoparticles. NanoImpact 8, 59-72. doi: 10.1016/j.impact.2017.07.006

Robledo, N., Vera, P., López, L., Yazdani-Pedram, M., Tapia, C., and Abugoch, L. (2018). Thymol nanoemulsions incorporated in quinoa protein/chitosan edible films; antifungal effect in cherry tomatoes. Food Chem. 246, 211-219. doi: 10.1016/j.foodchem.2017.11.032

Ryu, V., McClements, D. J., Corradini, M. G., Yang, J. S., and McLandsborough, L. (2018). Natural antimicrobial delivery systems: formulation, antimicrobial activity, and mechanism of action of quillaja saponinstabilized carvacrol nanoemulsions. Food Hydrocoll. 82, 442-450. doi: 10.1016/j.foodhyd.2018.04.017

Sakkas, H., Economou, V., Gousia, P., Bozidis, P., Sakkas, V. A., Petsios, S., et al. (2018). Antibacterial efficacy of commercially available essential oils tested against drug-resistant Gram-positive pathogens. Appl. Sci. 10:201. doi: 10.3390/app8112201

Salvia-Trujillo, L., Martin-Belloso, O., and Julian McClements, D. (2016). Excipient nanoemulsions for improving oral bioavailability of bioactives. Nanomaterials 6, 1-16. doi: 10.3390/nano6010017
Salvia-Trujillo, L., Qian, C., Martín-Belloso, O., and McClements, D. J. (2013). Influence of particle size on lipid digestion and $\beta$-carotene bioaccessibility in emulsions and nanoemulsions. Food Chem. 141, 1472-1480. doi: 10.1016/j.foodchem.2013.03.050

Salvia-Trujillo, L., Rojas-Graü, M. A., Soliva-Fortuny, R., and Martín-Belloso, O. (2015). Use of antimicrobial nanoemulsions as edible coatings: Impact on safety and quality attributes of fresh-cut Fuji apples. Postharvest Biol. Technol. 105, 8-16. doi: 10.1016/j.postharvbio.2015.03.009

Samriti, Biswas, R., and Biswas, K. (2018). Plant antimicrobial peptides: a novel approach against drug resistant microorganisms. Int. J. Pharm. Sci. Res. 9, 1-15. doi: 10.13040/IJPSR.0975-8232.9(1).1-15

Sanidad, K. Z., Sukamtoh, E., Xiao, H., McClements, D. J., and Zhang, G. (2019). Curcumin: recent advances in the development of strategies to improve oral bioavailability. Annu. Rev. Food Sci. Technol. 10, 597-617. doi: 10.1146/annurev-food-032818-121738

Savoia, D. (2012). Plant-derived antimicrobial compounds: alternatives to antibiotics. Future Microbiol. 7, 979-990. doi: $10.2217 / \mathrm{fmb}$. 12.68

Scalbert, A. (1991). Antimicrobial properties of tannins. Phytochemistry 30, 3875-3883.

Severino, R., Vu, K. D., Dons,ì, F., Salmieri, S., Ferrari, G., and Lacroix, M. (2014). Antibacterial and physical effects of modified chitosan based-coating containing nanoemulsion of mandarin essential oil and three non-thermal treatments against Listeria innocua in green beans. Int. J. Food Microbiol. 191, 82-88. doi: 10.1016/j.ijfoodmicro.2014.09.007

Shao, Y., Wu, C., Wu, T., Li, Y., Chen, S., Yuan, C., et al. (2018). Eugenolchitosan nanoemulsions by ultrasound-mediated emulsification: formulation, characterization and antimicrobial activity. Carbohydr. Polym. 193, 144-152. doi: 10.1016/j.carbpol.2018.03.101

Sharif, Z., Mustapha, F., Jai, J., Mohd Yusof, N., and Zaki, N. (2017). Review on methods for preservation and natural preservatives for extending the food longevity. Chem. Eng. Res. Bull. 19:145. doi: 10.3329/cerb.v19i0.33809

Sharma, H., Mendiratta, S. K., Agarwal, R. K., and Gurunathan, K. (2020). Biopreservative effect of blends of essential oils: natural anti-oxidant and antimicrobial agents for the shelf life enhancement of emulsion based chicken sausages. J. Food Sci. Technol. 57, 3040-3050. doi: 10.1007/s13197-020-04337-1

Sharma, S., Verma, H. N., and Sharma, N. K. (2014). Cationic bioactive peptide from the seeds of Benincasa hispida. Int. J. Pept. 2014:156060. doi: 10.1155/2014/156060

Shokri, S., Parastouei, K., Taghdir, M., and Abbaszadeh, S. (2020). Application an edible active coating based on chitosan-Ferulago angulata essential oil nanoemulsion to shelf life extension of rainbow trout fillets stored at $4^{\circ} \mathrm{C}$. Int. J. Biol. Macromol. 153, 846-854. doi: 10.1016/j.ijbiomac.2020.03.080

Simões, A., Veiga, F., Figueiras, A., and Vitorino, C. (2018). A practical framework for implementing quality by design to the development of topical drug products: nanosystem-based dosage forms. Int. J. Pharm. 548, 385-399. doi: 10.1016/j.ijpharm.2018.06.052

Sow, L. C., Tirtawinata, F., Yang, H., Shao, Q., and Wang, S. (2017). Carvacrol nanoemulsion combined with acid electrolysed water to inactivate bacteria, yeast in vitro and native microflora on shredded cabbages. Food Control 76, 88-95. doi: 10.1016/j.foodcont.2017.01.007

Srivastava, S., Dashora, K., Ameta, K. L., Singh, N. P., El-Enshasy, H. A., Pagano, M. C., et al. (2020). Cysteine-rich antimicrobial peptides from plants: the future of antimicrobial therapy. Phyther. Res. 35, 256-277. doi: 10.1002/ptr.6823

Sun, X-h., Zhou, T-t., Wei, C-h., Lana, W-q., Zhao, Y., Pan, Y-j. et al. (2018). Antibacterial effect and mechanism of anthocyanin rich Chinese wild blueberry extract on various foodborne pathogens. Food Control 94, 155-161. doi: 10.1016/j.foodcont.2018.07.012

Sutcliffe, J., Biedenbach, D., Jones, R., and Fritsche, T. (2008). "Novel nanoemulsion antimicrobials tested against nine Gram-positive species," in 48th Interscience Conference of Antimicrobial Agents and Chemotheraphy (Washington, DC: American Society for Microbiology).

Swamy, M. K., Akhtar, M. S., and Sinniah, U. R. (2016). Antimicrobial properties of plant essential oils against human pathogens and their mode of action: an updated review. Evidence Based Complement. Altern. Med. 2016:3012462. doi: $10.1155 / 2016 / 3012462$

Swanson, B. G. (1990). Pea and lentil protein extraction and functionality. J. Am. Oil Chem. Soc. 67, 276-280. doi: 10.1007/BF02539676 
Swathy, J. S., Mishra, P., Thomas, J., Mukherjee, A., and Chandrasekaran, N. (2018). Antimicrobial potency of high-energy emulsified black pepper oil nanoemulsion against aquaculture pathogen. Aquaculture 491, 210-220. doi: 10.1016/j.aquaculture.2018.03.045

Syed, I., and Sarkar, P. (2018). Ultrasonication-assisted formation and characterization of geraniol and carvacrol-loaded emulsions for enhanced antimicrobial activity against food-borne pathogens. Chem. Pap. 72, 2659-2672. doi: 10.1007/s11696-018-0501-z

Taheri, A., and Jafari, S. M. (2019). Gum-based nanocarriers for the protection and delivery of food bioactive compounds. Adv. Colloid Interface Sci. 269, 277-295. doi: 10.1016/j.cis.2019.04.009

Tahmasebi, M., Labbafi, M., Emam-Djomeh, Z., and Yarmand, M. S. (2016). Manufacturing the novel sausages with reduced quantity of meat and fat: the product development, formulation optimization, emulsion stability and textural characterization. $L W T$ 68, 76-84. doi: 10.1016/j.lwt.2015.12.011

Tajkarimi, M. M., Ibrahim, S. A., and Cliver, D. O. (2010). Antimicrobial herb and spice compounds in food. Food Control 21, 1199-1218. doi: 10.1016/j.foodcont.2010.02.003

Talón, E., Lampi, A. M., Vargas, M., Chiralt, A., Jouppila, K., and GonzálezMartínez, C. (2019). Encapsulation of eugenol by spray-drying using whey protein isolate or lecithin: release kinetics, antioxidant and antimicrobial properties. Food Chem. 295, 588-598. doi: 10.1016/j.foodchem.2019.05.115

Tam, J. P., Wang, S., Wong, K. H., and Tan, W. L. (2015). Antimicrobial peptides from plants. Pharmaceuticals 8, 711-757. doi: 10.3390/ph8040711

Tamene, D., and Endale, M. (2019). Antibacterial activity of coumarins and carbazole alkaloid from roots of Clausena anisata. Adv. Pharmacol. Sci. 2019:5419854. doi: 10.1155/2019/5419854

Tan, N., Yazici-Tütüniş, S., Bilgin, M., Tan, E., and Miski, M. (2017). Antibacterial activities of pyrenylated coumarins from the roots of Prangos hulusii. Molecules 22:1098. doi: $10.3390 /$ molecules 22071098

Tanhaeian, A., Sekhavati, M. H., and Moghaddam, M. (2020). Antimicrobial activity of some plant essential oils and an antimicrobial-peptide against some clinically isolated pathogens. Chem. Biol. Technol. Agric. 7:13. doi: 10.1186/s40538-020-00181-9

Teixeira, A. A. (2014). "Thermal food preservation techniques (pasteurization, sterilization, canning and blanching)," in Conventional and Advanced Food Processing Technologies, ed S. Bhattacharya (Hoboken: John Wiley \& Sons, Ltd), 115-128. doi: 10.1002/9781118406281.ch6

Thielmann, J., Muranyi, P., and Kazman, P. (2019). Screening essential oils for their antimicrobial activities against the foodborne pathogenic bacteria Escherichia coli and Staphylococcus aureus. Heliyon 5:e01860. doi: 10.1016/j.heliyon.2019.e01860

Ud-Daula, A. F. M. S., Demirci, F., Abu Salim, K., Demirci, B., Lim, L. B. L., Baser, K. H. C., et al. (2016). Chemical composition, antioxidant and antimicrobial activities of essential oils from leaves, aerial stems, basal stems, and rhizomes of Etlingera fimbriobracteata (K.Schum.) R.M.Sm. Ind. Crops Prod. 84, 189-198. doi: 10.1016/j.indcrop.2015.12.034

Upadhyay, A., Upadhyaya, I., Kollanoor-Johny, A., and Venkitanarayanan, K. (2014). Combating pathogenic microorganisms using plant-derived antimicrobials: a mini review of the mechanistic basis. Biomed Res. Int. 2014:761741. doi: 10.1155/2014/761741

Upadhyay, N., Singh, V. K., Dwivedy, A. K., Das, S., Chaudhari, A. K., and Dubey, N. K. (2019). Assessment of Melissa officinalis L. essential oil as an eco-friendly approach against biodeterioration of wheat flour caused by Tribolium castaneum Herbst. Environ. Sci. Pollut. Res. 26, 14036-14049. doi: 10.1007/s11356-019-04688-z

Varzakas, T., Zakynthinos, G., and Verpoort, F. (2016). Plant food residues as a source of nutraceuticals and functional foods. Foods 5:88. doi: $10.3390 /$ foods 5040088

Vinh, T. D. T., Hien, L. T. M., and Dao, D. T. A. (2020). Formulation of black pepper (Piper nigrum L.) essential oil nano-emulsion via phase inversion temperature method. Food Sci. Nutr. 8, 1741-1752. doi: 10.1002/fsn3.1422

Vitiello, G., Silvestri, B., and Luciani, G. (2018). Learning from nature: bioinspired strategies towards antimicrobial nanostructured systems. Curr. Top. Med. Chem. 18, 22-41. doi: 10.2174/1568026618666180206101129
Wani, T. A., Masoodi, F. A., Jafari, S. M., and McClements, D. J. (2018). "Safety of nanoemulsions and their regulatory status," in Nanoemulsions: Formulation, Applications, and Characterization, eds S. M. Jafari and D. J. McClements (Cambridge: Academic Press), 613-628. doi: 10.1016/B978-0-12-811838-2.00019-9

Weiss, J., Loeffler, M., and Terjung, N. (2015). The antimicrobial paradox: why preservatives loose activity in foods. Curr. Opin. Food Sci. 4, 69-75. doi: 10.1016/j.cofs.2015.05.008

Wong, J. H., and Ng, T. B. (2005). Lunatusin, a trypsin-stable antimicrobial peptide from Lima beans (Phaseolus lunatus L.). Peptides 26, 2086-2092. doi: 10.1016/j.peptides.2005.03.004

Wooster, T. J., Golding, M., and Sanguansri, P. (2008). Impact of oil type on nanoemulsion formation and Ostwald ripening stability. Langmuir 24, 12758-12765. doi: 10.1021/la801685v

Wu, C., Fu, S., Xiang, Y., Yuan, C., Hu, Y., Chen, S., et al. (2016a). Effect of chitosan gallate coating on the quality maintenance of refrigerated $\left(4^{\circ} \mathrm{C}\right)$ silver pomfret (Pampus argentus). Food Bioprocess Technol. 9, 1835-1843. doi: 10.1007/s11947-016-1771-5

Wu, C., Wang, L., Hu, Y., Chen, S., Liu, D., and Ye, X. (2016b). Edible coating from citrus essential oil-loaded nanoemulsions: physicochemical characterization and preservation performance. RSC Adv. 6, 20892-20900. doi: 10.1039/c6ra00757k

Xue, J., Davidson, P. M., and Zhong, Q. (2017). Inhibition of Escherichia coli $\mathrm{O} 157: \mathrm{H7}$ and Listeria monocytogenes growth in milk and cantaloupe juice by thymol nanoemulsions prepared with gelatin and lecithin. Food Control 73, 1499-1506. doi: 10.1016/j.foodcont.2016. 11.015

Yazgan, H. (2020). Investigation of antimicrobial properties of sage essential oil and its nanoemulsion as antimicrobial agent. LWT 130:109669. doi: 10.1016/j.lwt.2020.109669

Yazgan, H., Özogul, Y., Durmuş, M., Balikçi, E., Gökdogan, S., Uçar, Y., et al. (2017). Effects of oil-in-water nanoemulsion based on sunflower oil on the quality of farmed sea bass and gilthead sea bream stored at chilled temperature $\left(2 \pm 2^{\circ} \mathrm{C}\right)$. J. Aquat. Food Prod. Technol. 26, 979-992. doi: 10.1080/10498850.2017.1366610

Yeaman, M. R., and Yount, N. Y. (2003). Mechanisms of antimicrobial peptide action and resistance. Pharmacol. Rev. 55, 27-55. doi: 10.1124/pr. 55.1 .2

Yildirim, S. T., Oztop, M. H., and Soyer, Y. (2017). Cinnamon oil nanoemulsions by spontaneous emulsification: formulation, characterization and antimicrobial activity. LWT 84, 122-128. doi: 10.1016/j.lwt.2017. 05.041

Zhang, C., Guanming, S., Shen, J., and Hu, R. F. (2015). Productivity effect and overuse of pesticide in crop production in China. J. Integr. Agric. 14, 1903-1910. doi: 10.1016/S2095-3119(15)6 1056-5

Zhang, S., Zhang, M., Fang, Z., and Liu, Y. (2017). Preparation and characterization of blended cloves/cinnamon essential oil nanoemulsions. LWT 75, 316-322. doi: 10.1016/j.lwt.2016.08.046

Zhang, Y., Liu, X., Wang, Y., Jiang, P., and Quek, S. Y. (2016). Antibacterial activity and mechanism of cinnamon essential oil against Escherichia coli and Staphylococcus aureus. Food Control 59, 282-289. doi: 10.1016/j.foodcont.2015. 05.032

Conflict of Interest: The authors declare that the research was conducted in the absence of any commercial or financial relationships that could be construed as a potential conflict of interest.

Copyright (๑ 2021 McClements, Das, Dhar, Nanda and Chatterjee. This is an openaccess article distributed under the terms of the Creative Commons Attribution License (CC BY). The use, distribution or reproduction in other forums is permitted, provided the original author(s) and the copyright owner(s) are credited and that the original publication in this journal is cited, in accordance with accepted academic practice. No use, distribution or reproduction is permitted which does not comply with these terms. 